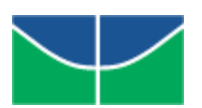

Universidade de Brasília - UnB

Faculdade de Economia, Administração, Contabilidade e Ciência da Informação e Documentação (FACE)

Programa de Pós Graduação em Administração (PPGA)
\end{abstract}

Aureli Oliveira Jurumenha Turra

DEMOCRACIA E PARTICIPAÇÃO: CONTROLE SOCIAL DO FUNDEB ESTUDO DE CASO NO MARANHÃO E PIAUÍ

Brasília - DF 


\title{
DEMOCRACIA E PARTICIPAÇÃO: CONTROLE SOCIAL DO FUNDEB ESTUDO DE CASO NO MARANHÃO E PIAUÍ
}

\author{
Monografia apresentada ao Programa de Pós \\ Graduação em Administração (PPGA) da \\ Faculdade de Economia, Administração, \\ Contabilidade e Ciência da Informação e \\ Documentação (FACE), da Universidade de \\ Brasília, como requisito necessário à obtenção do \\ título de especialista em Gestão de Programas e \\ Projetos Educacionais.
}

Orientadora: Prof ${ }^{a}$. Dra. Sayonara de Amorim Gonçalves Leal 
Aos meus amados filhos. Priscila e 7iaga, fonte dos meus maiores sanhos, que me estimulam a evidenciar que pademos atingir tados as nossos abjetivas, se tivermas determinaçãa, dedicaçãa e disciplina para lutar em busca de seu alcance, cam a visãa de que vencedares nãa sãa aqueles que nunca falham, mas as que nunca desistem. 


\section{Agradecimentos}

A Deus, meu Senhor, Autor da minha vida e fé, que me permitiu chegar até aqui, com saúde, garra e disposição.

Ao Sérgio, meu esposo, meu amor, amigo e companheiro de todas as horas, pela tolerância às minhas constantes ausências e pelo carinho, apoio e compreensão dispensados durante o período do curso, não medindo esforços para que eu ultrapassasse esta etapa em minha vida.

À professora e orientadora Sayonara Leal, pelo rigor e seriedade com que desempenhou sua função, pela disposição em me atender sempre, pela segurança na orientação e pelo incentivo e inspiração no amadurecimento dos meus conhecimentos e conceitos, que me levaram à elaboração desta monografia, tornando possível a sua conclusão.

Aos demais professores do PPGA-UnB, pelos conhecimentos transmitidos, que contribuíram para a minha formação acadêmica, profissional e pessoal.

Ao FNDE, por me ter proporcionado mais essa oportunidade.

Aos meus superiores imediatos, Vander e Toninho, por terem me apoiado nessa empreitada.

Aos colegas da Coordenação de Operacionalização do Fundeb, por terem carregado o "fardo" com comprometimento e dedicação nos períodos em que eu estava participando do curso.

A todos os colegas de curso, com os quais dividi momentos de angústias e de alegria durante esse período.

Aos conselheiros do Fundeb do Maranhão e Piaú que participaram desta pesquisa e demonstraram ser cidadãos corajosos no desempenho da nobre tarefa de lutar pela qualidade da educação básica brasileira. 
"Nãa pademas dizer: aqui terminam os meus deveres cama cidadãa e cameça a minha liberdade cama individua. Estas duas identidades existem numa tensãa permanente, que nunca pade ser conciliada. Mas é precisamente a tensãa entre a liberdade $e$ a igualdade que caracteriza a demacracia moderna". Chantal Mouffe

"A liberdade e a iqualdade dos homens nãa sãa um dado de fata, mas un ideal a persequir; nãa sãa una existência, mas un valor; nãa sãa un ser, mas um dever ser." Norberta Babbia 


\section{RESUMO}

O controle social pode ser definido como a participação da sociedade civil no que diz respeito à gestão da coisa pública. Esse controle social pode ser exercido por meio de conselhos que se caracterizam em colegiados, representados por diversos segmentos da sociedade civil. Embora muitos desses conselhos tenham uma atuação limitada, esses colegiados têm demonstrado um grande exercício cívico no que tange à preocupação do cidadão com a res publica, praticando, dessa forma, sua cidadania. Para que isso ocorra de fato, é importante que se demonstre a importância em se buscar elementos que possam revitalizar as potencialidades da relação entre sociedade e Estado para realização da política, porque é nela que se encontram as oportunidades para solução de problemas públicos. Disso decorre a importância de se investigar os canais de participação popular que ampliam as possibilidades de inserção dos cidadãos nas decisões políticas que lhes dizem respeito. No caso específico do presente estudo, a relevância do tema justifica-se pelo fato de que o impacto da aplicação dos recursos do Fundo de Manutenção e Desenvolvimento da Educação Básica e de Valorização dos Profissionais da Educação (Fundeb) recai sobre a qualidade da educação básica pública brasileira. Estudar, portanto, o funcionamento do processo de acompanhamento da aplicação de recursos públicos na educação brasileira traz uma contribuição para trazer à tona o debate sobre a estrutura e o contexto dos conselhos do Fundeb nos estados e municípios. Com base em pesquisa qualitativa, este estudo foi operacionalizado a partir da adoção das técnicas de entrevista semi-estruturada, aplicação de questionários, análise documental. O objetivo foi analisar o funcionamento e a eficácia dos Conselhos de Acompanhamento e Controle Social do Fundeb nos estados do Maranhão e Piaú, identificando dificuldades presentes no acompanhamento da aplicação desses recursos e fornecer subsídios ao Fundo Nacional de Desenvolvimento da Educação (FNDE) para melhor capacitar esses colegiados a atuarem de forma mais autônoma e eficaz na aplicação de recursos do Fundo, perseguindo, nesse intuito, a plenitude da participação da sociedade na gestão da coisa pública.

\section{Palavras-chaves: Democracia; política; controle social; conselhos do Fundeb}




\section{SUMÁRIO}

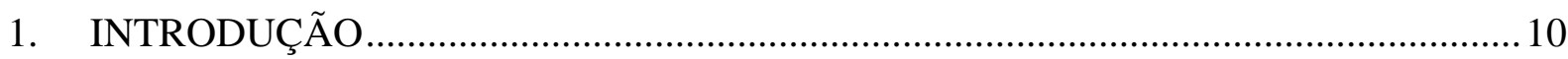

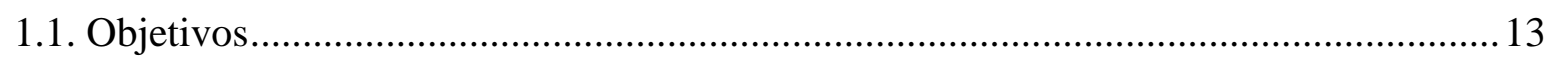

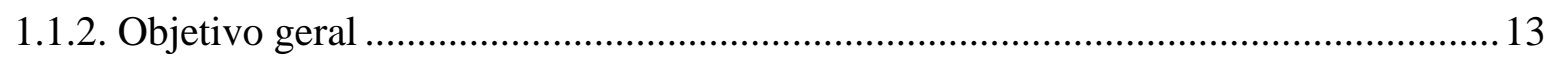

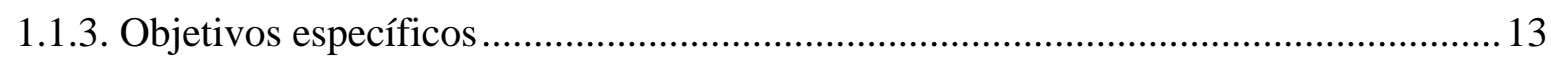

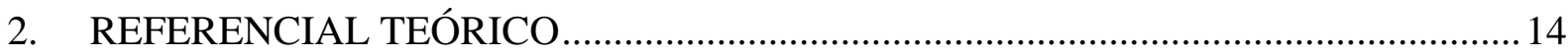

2.1. Conceito de democracia: entre representação e participação ....................................... 14

2.2. Política e esfera pública: democracia fortalecida .....................................................22

2.3. Espaços públicos e controle social sobre a coisa pública: o papel dos conselhos no

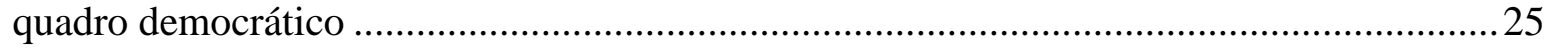

2.4. A conquista da cidadania no Brasil: uma reflexão sobre política, democracia e esfera

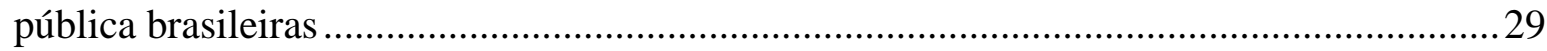

2.5. O exercício da democracia participativa no Brasil por meio do controle social ............33

3. O FUNDO DE MANUTENÇÃO E DESENVOLVIMENTO DA EDUCAÇÃO BÁSICA E DE VALORIZAÇÃO DOS PROFISSIONAIS DA EDUCAÇÃO (FUNDEB) E SEU CONSELHO DE ACOMPANHAMENTO E CONTROLE SOCIAL …................................. 38

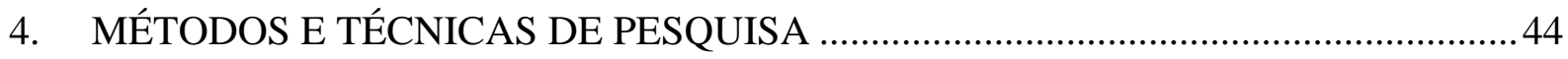

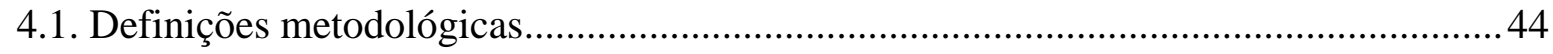

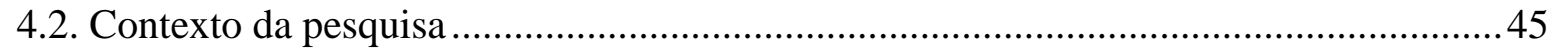

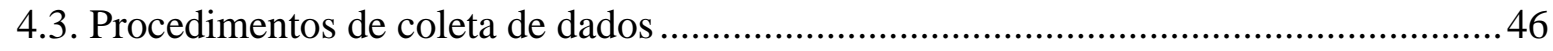

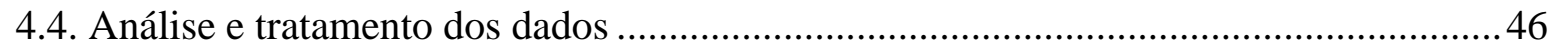

5. ESTUDO DE CASO: os conselhos do Fundeb no Maranhão e no Piauí.............................. 48

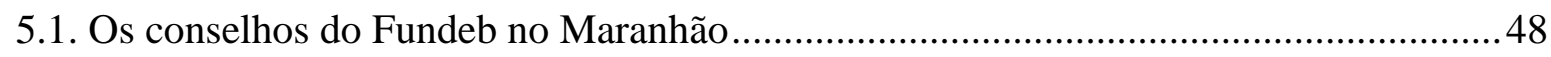

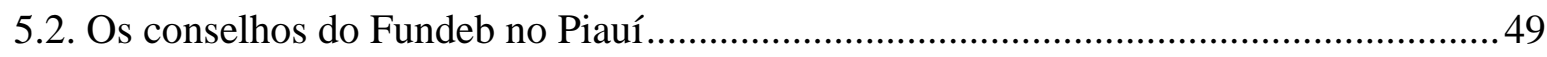

5.3. Os conselhos como espaços públicos ........................................................................ 50

5.4. Os conselhos como mecanismos de controle social na gestão da educação básica

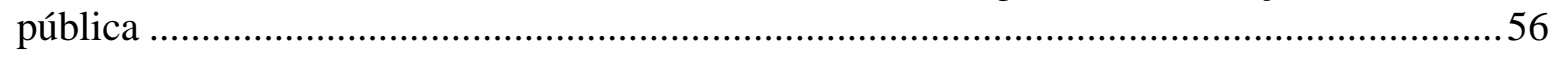

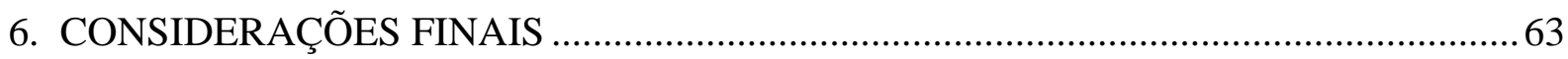

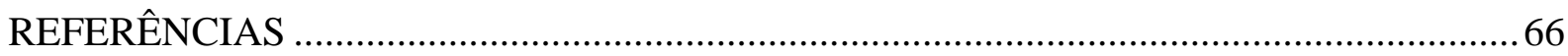




\section{LISTA DE QUADROS}

Quadro 1 - Recursos que compõem o Fundeb .......................................................... 40

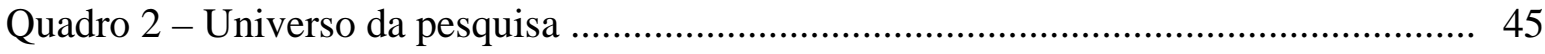

Quadro 3 - História dos conselhos ............................................................................. 52

Quadro 4 - Perfil sociológico dos conselheiros participantes pesquisa ............................ 54

Quadro 5 - Atuação dos conselhos ........................................................................... 58

Quadro 6 - Entendimento dos conselheiros sobre necessidade de capacitação ................. 61 


\section{LISTA DE GRÁFICOS}

Gráfico 1 - Periodicidade das reuniões .................................................................. 53

Gráfico 2 - Motivação para compor o Conselho ......................................................... 60

Gráfico 3 - Entendimento sobre o significado de controle social ..................................... 60 


\section{INTRODUÇÃO}

Um dos temas mais recorrentes no debate atual sobre o desempenho do Estado contemporâneo sob o auspício do sistema político democrático são as mudanças políticas nas instâncias do poder público central, permitindo certa descentralização do poder decisório do ente estatal em favor de mecanismos de participação cidadã, como audiências, consultas públicas e conselhos gestores, deliberativos e consultivos. O presente trabalho parte da

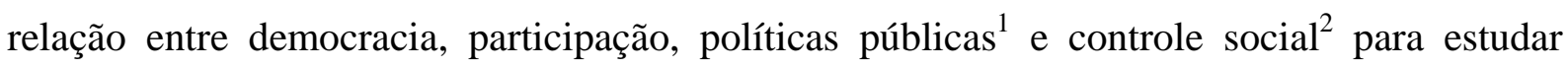
primeiro a partir de uma reflexão teórica a respeito dessas categorias e depois sua aplicação no tratamento do controle social exercido pelo cidadão sobre o Fundo de Manutenção e Desenvolvimento da Educação Básica e de Valorização dos Profissionais da Educação (Fundeb), como decorrente de uma política pública educacional, especificamente nos estados do Maranhão e Piauí.

Em diversos países democráticos está havendo uma abertura do poder Executivo à participação da sociedade civil, investida juridicamente como representante de segmentos e interesses da população no desenho, na implementação e na supervisão de políticas públicas. Semelhante ao que aconteceu nas primeiras décadas do século XX, quando as instituições da representação política foram alargadas juntamente com a própria democracia, mediante a emergência dos partidos de massa, esses processos de reconfiguração da representação, englobando o poder Executivo, podem confluir para uma nova ampliação da democracia (LAVALLE; HOUTZAGER; CASTELLO, 2006).

Ao observar o estado da democracia em países de pouco tradição democrática, como as nações latino-americanas, a partir da década de 1980, percebe-se que sucessivas transformações na conscientização dos cidadãos estão ocorrendo de forma inevitável, provocando mudanças na forma de se fazer política e elaborar políticas públicas. No Brasil, mais precisamente após a Constituinte de 1988, alterou-se a maneira como interagem os mais diversos agentes sociais e políticos em nível local e regional na busca de estratégias adequadas que promovam a democracia e o desenvolvimento. As práticas de gestão pública vêm sendo modificadas e a participação da sociedade civil e do cidadão tem conquistado importância nesse contexto.

\footnotetext{
${ }^{1}$ Entende-se por políticas públicas, o conjunto de ações coletivas voltadas para a garantia dos direitos sociais, configurando um compromisso público, expressanso a transformação daquilo que é do âmbito privado em ações coletivas no espaço público.

${ }^{2}$ Na perspectiva deste trabalho, controle social é a participação do cidadão por meio de organizações representativas na formulação das políticas públicas e no controle da execução das ações dos administradores públicos, especialmente nas chamadas políticas sociais.
} 
A experiência do Brasil em termos de democracia participativa, por exemplo, tem se repercutido mundialmente. Conforme Lavalle (2006, p. 5), "talvez pela primeira vez na história, a democracia e seu horizonte de reformas possíveis passaram a ser pensados no hemisfério norte a partir das experiências vivenciadas no hemisfério sul”. Atualmente, têm acontecido intensos debates no país em torno da melhor maneira de exercer a democracia. Diversos segmentos sociais têm buscado participar de maneira mais ativa das decisões políticas tomadas no âmbito do Estado. Disso decorre a idéia de aperfeiçoar os mecanismos democráticos vigentes.

Nesse sentido, a sociedade brasileira e a esfera pública política ${ }^{3}$ vêm gradativamente se movimentando em torno da grande necessidade de implementação de mudanças nos sistemas de controle sobre os recursos públicos, ampliando-se os meios de controle social. Esse aumento do controle social não pode, entretanto, significar a imobilização da ação do gestor público, mas a garantia de uma utilização mais racional, eficiente, transparente, regular e compatível com o esforço de submissão da sociedade à tributação imposta pelo Estado.

É essencial que se demonstre a importância em se buscar elementos que possam revitalizar as potencialidades do Estado e da política, para que se encontre neles oportunidades de solução de problemas. Daí a necessidade de se investigar os canais de participação popular que ampliem as possibilidades de inserção dos cidadãos nas decisões políticas que lhes dizem respeito.

O cenário atual do Brasil, de ampla disputa política, diante das transformações sociais do final do século XX e início do século XXI, apresenta fragilidades em seu modelo de democracia. Com isso, as mudanças necessárias no controle devem caminhar na direção de ampliação e consolidação da democracia brasileira e, dessa forma, as transformações decorrentes de reformas administrativas estão caminhando na direção de ampliação do controle social, fator fundamental para ampliação da democracia. Entretanto, ainda são tímidos os meios que permitem o exercício de tal controle pela sociedade, além do despreparo do cidadão para lidar com conteúdos específicos e instrumentos bilaterais de gestão da coisa pública, tais como audiências e consultas públicas.

Conseqüentemente, o controle social na aplicação dos recursos públicos colocados à disposição do Estado é um tema extremamente importante para ser discutido, até pelo motivo do país, nos últimos anos, ter se defrontado com inúmeros casos de desvios e impropriedades

\footnotetext{
${ }^{3}$ Entende-se por esfera pública política uma esfera de pessoas privadas reunidas num público e que reivindicam esta esfera pública regulamentada pela autoridade, porém diretamente contra a própria autoridade, objetivando discutir as leis gerais do intercâmbio de mercadorias e do trabalho social (HABERMAS, 2003).
} 
na execução do gasto público, fazendo com que esses dados imponham a necessidade de discussões sobre o tema controle social, pois pode se está acumulando um elevado custo social pela má utilização de recursos públicos (SILVA, 2001). Não se pode, portanto, pensar contemporaneamente a gestão pública federal, estadual ou municipal sem se articular os conceitos $^{4}$ de participação, cidadania, democracia e descentralização, já que esses conceitos estão aportados nas práticas sociais desenvolvidas tanto pelos governos quanto pela sociedade civil (ALLEBRANDT, 2002).

Nesse contexto, verifica-se que a função do controle social sobre a atuação e resultados da política pública é de fundamental importância para o desenvolvimento de programas governamentais. Para que o acompanhamento dessas políticas seja realizado de forma eficaz nos estados e municípios brasileiros, é necessário que haja conscientização dos cidadãos de que eles devem participar das decisões de interesse público, promovendo, dessa forma, uma melhor atuação desses cidadãos no processo democrático.

No caso do controle social dos recursos da educação, especificamente no que concerne ao Fundeb nos estados do Maranhão e Piauí, onde se tem um dos menores valores per-capita por aluno/ano e onde freqüentemente ocorre má aplicação de recursos públicos (conforme reclamações feitas ao Ministério da Educação pela sociedade civil desses dois estados), faz-se necessário investigar se os Conselhos de Acompanhamento e Controle Social do Fundeb estão assumindo suas funções conforme previsto em seu regulamento, de acordo com o compromisso com a res publica. O tema da democracia vinculado ao exercício da participação estimulou o interesse em estudar como os conselhos do Fundeb exercem o controle social sobre os recursos da educação básica.

A relevância desse estudo justifica-se pela importância da aplicação dos recursos do Fundeb recair sobre a qualidade da educação básica pública no Brasil e, conseqüentemente, sobre o aluno-cidadão. O estudo do "desenrolar do jogo" nos Conselhos de Acompanhamento e Controle Social do Fundeb nos estados do Maranhão e Piauí, portanto, passa pela problematização do controle social efetivo do público de cidadãos a partir dos conselhos nos dois estados. A apreciação analítica e crítica dos conselhos interessa diretamente ao Fundo Nacional de Desenvolvimento da Educação (FNDE) visto que se trata

\footnotetext{
${ }^{4}$ No contexto apresentado neste trabalho, entende-se por participação, a democratização do conhecimento do processo dos serviços públicos, estimulando a organização da comunidade, para o efetivo exercício do controle social, na gestão da coisa pública; por cidadania a efetivação moral e social da busca pela conquista e garantia dos direitos para a construção de uma sociabilidade regida por interesses coletivos; por democracia, a forma de governo em que o poder não está nas mãos de um só ou de poucos, mas da maior parte, contrapondo-se às formas autocráticas; por descentralização, a transferência de responsabilidade pelo acompanhamento e fiscalização da instância governamental para a sociedade civil, gerando mais transparência nas políticas públicas e na administração local.
} 
das funções dos conselhos como mecanismo de controle social no acompanhamento da aplicação de recursos públicos na Educação no país. Dessa forma, será apresentada neste trabalho uma percepção política, sociológica e histórica do papel fundamental do controle social como parte do processo sistêmico de regulação do Estado, no que concerne à educação.

\subsection{Objetivos}

\subsubsection{Objetivo geral}

- Este estudo tem por objetivo geral analisar o funcionamento e a eficácia dos Conselhos de Acompanhamento e Controle Social do Fundeb como locus de participação democrática e cidadã, tendo como referência empírica os conselhos atuantes em dois estados brasileiros, Maranhão e Piauí.

\subsubsection{Objetivos específicos}

- Identificar as dificuldades presentes no acompanhamento dos conselhos na aplicação de recursos do Fundeb, comparando-os com os descritos pela literatura;

- Fornecer subsídios ao FNDE para melhor capacitar os Conselhos de Acompanhamento e Controle Social do Fundo, possibilitando que esses colegiados executem suas funções de forma mais autônoma, consciente e eficaz no acompanhamento da aplicação de recursos do Fundeb. 


\section{REFERENCIAL TEÓRICO}

Esse tópico apresenta uma revisão de literatura sobre os conceitos de democracia, cidadania, espaço público e controle social, necessária ao desenvolvimento deste trabalho, dando suporte aos assuntos abordados, em função do tema escolhido: Democracia, participação e controle social por meio dos conselhos do Fundeb nos estados do Maranhão e Piauí. Inicia-se com o conceito de democracia representativa e participativa. Em seguida discute-se a democracia política e a esfera pública; os espaços públicos e o controle social sobre a coisa pública; a conquista da cidadania no Brasil e como se dá a prática da democracia participativa no país. O tópico se encerra com a apresentação de discussão sobre o exercício da democracia participativa mediante o controle social no caso específico dos conselhos do Fundeb.

\subsection{Conceito de democracia: entre representação e participação}

A democracia moderna, em sentido mais amplo, pode ser compreendida como uma forma de governo pautado nas leis, nas liberdades civis e políticas, significando um regime fundado nos princípios de igualdade e liberdade de pensamento, expressão e organização. Em sentido mais restrito, democracia refere-se à forma de governo em que os cidadãos de um Estado têm a oportunidade de participar livremente das decisões políticas que lhes afetam a vida individual e coletiva (COELHO, 2007). Etimologicamente, democracia diz respeito ao governo do e para o povo. No entanto, sabemos das limitações de ordem demográfica e geográfica e das especificidades históricas, políticas e econômicas que inviabilizaram o modelo de democracia direta, típica dos gregos atenienses na antiguidade e favoreceram a democracia indireta. A democracia moderna se funda no pensamento liberal-burguês e assume forma hegemônica representativa, distanciando-se do modelo direto e admitindo pouca abertura para mecanismos semi-diretos (mais participativos). Mas, sinais de limitações do regime democrático de massa, apoiado na representação, manifestam-se no próprio desempenho da esfera pública política, sobretudo do Estado e Parlamento, fazendo pouco a pouco se fortalecerem demandas sociais por mecanismos de participação mais direta do cidadão na gestão da coisa pública, reconhecidos pelo poder público e institucionalizados por este, como fruto da problematização da democracia liberal representativa, que, segundo Bobbio (2006), nasceu de uma concepção individualista da sociedade, ou seja, da concepção segundo a qual a sociedade é um produto artificial da vontade dos indivíduos. No compasso 
de Bobbio, Bovero (2002) define a democracia como um regime político no qual todos os sujeitos aos quais são dirigidas as decisões coletivas têm o direito de participar, todos com igual peso.

Como é de amplo conhecimento, a democracia surgiu com a perspectiva de eliminar definitivamente o poder invisível das sociedades humanas e de dar vida a um governo cujas ações deveriam ser desenvolvidas publicamente (BOBBIO, 1992). Para o autor (1992), o princípio inspirador do pensamento democrático sempre foi a liberdade entendida como autonomia, que é a capacidade de dar leis a si própria e que deveria ter como conseqüência a perfeita identificação entre quem dá e quem recebe uma regra de conduta.

A democracia, conforme Bobbio (2006), é o conjunto de regras (primárias ou fundamentais) que estabelecem quem está autorizado a tomar as decisões coletivas e com quais procedimentos e tem como regra fundamental a regra da maioria, à base da qual são consideradas decisões coletivas e vinculatórias para todo o grupo. Isso significa que as decisões são aprovadas ao menos pela maioria daqueles a quem compete tomar a decisão, já que todo grupo social deve necessariamente tomar decisões vinculatórias para todos os seus componentes, com o objetivo de trazer provimento à própria sobrevivência, tanto interna como externamente.

A democracia representativa, por sua vez, significa para Bobbio (2006) que as deliberações coletivas são tomadas por pessoas eleitas para essa finalidade e não diretamente por aqueles que dela fazem parte. Ele afirma, porém, que nem toda forma de democracia é representativa e nem todo Estado representativo é um Estado democrático, pelo simples fato de ser representativo. As regras de procedimentos que tornam possível a democracia representativa, nos termos de Bobbio, distanciam-se da democracia direta, porque esta permite a participação de todos os cidadãos em todas as decisões a eles pertinentes. É justamente nesse ponto que o autor reconhece que essa participação direta é materialmente impossível, dada à impossibilidade de fazer com que todos decidam sobre tudo em sociedades complexas como as nossas.

Daí se dá o Estado representativo, entendido como uma forma específica de constituição política, que prevê a existência de um órgão colegiado, cujos membros representam os cidadãos (BOVERO, 2002). Todavia, para uma definição mínima de democracia, não basta que o direito de participar direta ou indiretamente da tomada de decisões seja atribuído a um elevado número de cidadãos, nem mesmo é suficiente a adoção de regras de procedimento, como regra da maioria. É necessário que aqueles que são chamados para decidir ou para eleger os que decidirão, estejam diante de alternativas reais e 
em condições de escolher entre essas alternativas. As normas constitucionais que atribuem esses direitos não são exatamente regras do jogo e sim, regras preliminares que permitem o desenrolar desse jogo (BOBBIO, 2006).

Bobbio (2006) defende uma democracia indireta que viesse a exigir dos cidadãos a sua participação em todas as decisões relacionadas aos seus interesses. Segundo o autor, os partidários da democracia direta, conforme a tradição do pensamento socialista, a colocam em oposição à democracia representativa, considerada como a ideologia própria da burguesia mais avançada, ou seja, a ideologia burguesa da democracia. Nessa mesma linha de pensamento, Bobbio sustenta que o defeito da democracia representativa, em relação à democracia direta, consiste na tendência à formação de pequenas oligarquias, que são os comitês dirigentes dos partidos, visto que o princípio sobre o qual se fundamenta a representação política é o contrário do princípio sobre o qual se fundamenta a representação dos interesses particulares do representado.

Para o autor, a democracia moderna, surgida como democracia representativa em contraposição à democracia dos antigos, deveria ser caracterizada pela representação política, ou seja, por uma forma de representação na qual o representante não estaria sujeito a um mandato vinculado, já que foi chamado para perseguir os interesses da nação e não os seus direitos.

Em uma análise realizada por Bobbio (2006), podemos inferir que o autor adota a perspectiva do contraste entre os ideais de ontem (teorias como as de Rousseau, Locke, e Stuart Mill) e a matéria bruta de hoje (a atual conjuntura das democracias representativas), o que foi prometido e o que foi realizado. Isso se traduz em promessas não-cumpridas, as quais podem ser ordenadas da seguinte forma: i) o ideal seria o da representação política (o representante representando apenas a nação), mas na prática se deu o inverso: o representante freqüentemente representa interesses particulares; ii) a que está relacionada com o poder oligárquico: o projeto democrático preconizava a eliminação da distinção entre governantes e governados - como resultado, contudo, temos que a própria forma da democracia representativa já é a negação daquele projeto e que não somente as oligarquias não foram suprimidas, como hoje também temos a presença de toda uma gama de elites; e iii) a que trata do "poder invisível": o primeiro ideal da democracia era o da transparência - todas as ações do governo deveriam ser públicas e nenhum outro tipo de poder secreto seria legítimo - mas hoje temos, de um lado, alguns poderes sociais anômalos e encobertos, e de outro, a tendência do governo de passar do seu papel de observado-controlado ao de observador-controlador. 
Para Bobbio (2006), tais promessas não se realizaram devido a certos obstáculos imprevistos relacionados ao grau de complexidade das sociedades contemporâneas. No entanto, a conclusão do autor é positiva e moderadamente otimista: os direitos com base na liberdade individual, o pluralismo partidário, o sufrágio universal, entre outras instâncias fundamentais do Estado democrático, têm permanecido atuantes e, apesar de algumas democracias estarem mais ou menos distantes do paradigma ideal e original de regime democrático, nenhuma delas se assemelha, constitutivamente, a um Estado de tipo autocrático.

Por fim, Bobbio (2006) depreende que o processo de democratização consiste não na passagem da democracia representativa para a direta, mas na ocupação, pelas formas ainda tradicionais da democracia, como é a representativa, de espaços até agora dominados por organizações de tipo hierárquico e burocrático.

Segundo Bobbio (1992), se a democracia não consegue derrotar totalmente o poder oligárquico, ela é ainda menos capaz de ocupar todos os espaços nos quais se exerce um poder, onde se toma decisões vinculatórias para um grupo social como um todo. O autor entende que quando se deseja saber se houve um desenvolvimento da democracia em um país, o certo é procurar perceber se aumentaram os espaços nos quais os cidadãos podem exercer este direito e não o número dos que têm o direito de participar nas decisões que lhes dizem respeito.

Já Habermas (2002) formula sua crítica ao modelo liberal representativo de democracia, condensando o debate atual da democracia em três modelos normativos, construídos a partir de uma análise da relação entre Estado e sociedade, buscando identificar o lugar da política entre esses dois atores. Esses três modelos são: o modelo liberal, o modelo republicano e o modelo deliberativo.

Conforme Habermas (2002), o modelo liberal se fundamenta em uma comunidade econômica e dá ênfase aos direitos individuais, tendo o mercado como seu paradigma. Esse modelo é baseado na democracia representativa e define sua política centrada no Estado. O modelo republicano se fundamenta em uma comunidade ética, compreendendo a democracia como sinônimo de auto-regulamentação política da sociedade e baseia-se na solidariedade como fonte de integração social. Esse modelo tem como paradigma a interlocução na sociedade, ou seja, define sua política centrada na sociedade, enfatizando a democracia participativa. Já o modelo deliberativo, formulado por Habermas (2002), se concentra na defesa das condições de comunicação do cidadão, acolhendo elementos dos outros dois modelos, mas pendente ao viés republicano. 
Para Habermas (2002), o modelo deliberativo vislumbra as questões éticas diferentemente das questões de justiça, que possuem validade para além de uma comunidade jurídica concreta, obedecendo ao processo de uma comunicação fluente, havendo, dessa forma, entendimento mútuo de todas as partes envolvidas em um processo. Além disso, esse modelo ainda compreende a política como um sistema de ação ao lado de outros sistemas e não no topo ou na base da sociedade.

No debate entre o modelo liberal e o modelo republicano, entre a democracia representativa e a democracia direta, a posição de Habermas (2002) é a de reunir aspectos dos dois modelos, com a concepção procedimentalista de uma política deliberativa, que dá origem à chamada democracia deliberativa. Para Habermas, o conceito de uma política deliberativa só adquire uma referência empírica quando se faz jus à diversidade das formas comunicativas na qual se constitui uma vontade comum pela busca de equilíbrio entre interesses divergentes, do estabelecimento de acordos e de uma escolha de instrumentos racionais e voltada a um fim específico e não apenas por um auto-entendimento mútuo de caráter ético.

Ainda, segundo o autor (2002), quando o conceito procedimental da política deliberativa se torna o centro consistente da teoria sobre a democracia, a sociedade terá resultados diferentes, tanto na concepção republicana do Estado como uma comunidade ética, quanto em relação à concepção liberal do Estado como defensor de uma sociedade econômica.

Giddens (2001), em sua versão dialógica de democracia, entende que nessa era de globalização os políticos nacionais têm um controle menor sobre algumas das influências que afetam seus cidadãos. No entanto, a reforma do governo e dos mecanismos do Estado pode contribuir para que se recupere o equilíbrio na atual sociedade, dotada de ampla informação, onde as democracias estabelecidas não são suficientemente democráticas. Para o autor, há necessidade de uma democratização da democracia.

Segundo Giddens (2001), essa democratização exige diferentes políticas, dependendo da história do país e de seu nível de democracia anterior. Alguns entendem que essa democracia envolve a reforma constitucional, o despojamento de símbolos e privilégios arcaicos, além de medidas para introduzir maior transparência e responsabilidade. Giddens, no entanto, entende que no desenvolvimento de um sistema de informação, as fronteiras entre o que é comportamento político aceitável e o que é visto por muitos como corrupto são alteradas. As práticas deturpadas da gestão realizadas no meio político e por alguns cidadãos não são mais aceitas pela maioria da população e devem ser o alvo principal da democratização da democracia. Por esse motivo, as novas reivindicações de transparência do 
poder público e suas instituições estão sendo feitas, não apenas por instituições políticas, mas também por outros setores, o que é uma característica lógica de uma sociedade em que o acesso à informação é muito mais fácil do que antes e onde a opinião sobre o sigilo está mudando.

A democratização da democracia, conforme Giddens (2001), deve acompanhar a influência da globalização e por essa razão, ela implica a devolução do poder a localidades e regiões. Nesse sentido, entende-se que o conceito procedimental de democracia deliberativa, nos termos habermasianos, é mais pertinente à imagem de uma sociedade descentralizada, que na verdade diferencia e autonomiza com a opinião pública um cenário propício à constatação, identificação e tratamento de problemas que envolvem a sociedade como um todo.

Depreende-se da discussão conceitual de modelos de democracia, que Bobbio defende a democracia indireta, Habermas a democracia deliberativa e Giddens a democracia dialógica. No entanto, há muitos pontos de convergência entre essas concepções, além de pontos definidos em outros modelos de democracia, como a democracia participativa. No debate entre comunitaristas e universalistas, ou entre republicanos e liberais, a posição de Habermas, assim como a de autores como Giddens, é de um universalismo dotado de uma marcada sensibilidade para as diferenças, defendendo o diálogo e a convivência entre as culturas, como uma forma de integração social. Portanto, como se fosse um círculo virtuoso, no exercício da política deve-se haver, a todo o momento, também o exercício continuado da democracia política.

Nessa perspectiva, outros autores defendem a democracia participativa, que, do ponto de vista teórico, apresenta possibilidades para conciliar o tradicional instituto da representação política, fundamental para os governos democráticos, com maior inserção dos cidadãos na vida política. Para tanto, muitos estudiosos entendem que se devem ampliar as possibilidades participativas, coletivas e individuais, tanto do ponto de vista quantitativo, para oferecer aos cidadãos uma maior disponibilidade de instrumentos de participação das decisões políticas do que as já existentes; como qualitativo, para que espaços participativos se tornem, cada vez mais, espaços de decisão política, devolvendo o poder a seu legítimo detentor e, ainda, para que os próprios instrumentos tradicionais de representação política possam se aperfeiçoar.

Santos (2002) depreende que o modelo da democracia puramente representativa revela-se uma democracia de baixa intensidade, baseada na privatização do bem público por elites muitas vezes restritas, possibilitando a existência de uma crescente distância entre os representantes e seus representados e em uma inclusão política abstrata, feita de exclusão social. Para o autor, a solução para esse desafio, no entanto, não seria a extinção do modelo de 
democracia representativa, mas no seu aperfeiçoamento, que seria a adoção da democracia participativa. Nessa linha de pensamento, Santos apresenta três teses para o fortalecimento da democracia participativa:

$1^{\text {a }}$ tese: pelo fortalecimento da demodiversidade. Essa tese implica reconhecer que não existe nenhum motivo para a democracia assumir uma só forma. Pelo contrário, o multiculturalismo e as experiências recentes de participação apontam no sentido da deliberação pública ampliada e do adensamento da participação...

$2^{\mathrm{a}}$ tese: fortalecimento da articulação contra-hegemônica entre o local e o global. Novas experiências democráticas precisam do apoio de atores democráticos transnacionais nos casos nos quais a democracia é fraca... Portanto, a passagem do contra-hegemônico do plano local para o global é fundamental para o fortalecimento da democracia participativa.

$3^{\text {a }}$ tese: ampliação do experimentalismo democrático. ...As novas experiências bem sucedidas se originaram de novas gramáticas sociais nas quais o formato da participação foi sendo adquirido experimentalmente... (SANTOS, 2002, p. 77).

Para Santos (2002), a importância da participação atinge dimensões tão grandes que adquire vultosas proporções na transformação da democracia. Em seu entender, há um confronto entre a democracia representativa e a participativa. Esse confronto decorre do fato da democracia representativa rejeitar a legitimidade da democracia participativa e isso só terá solução na medida em que essa rejeição for substituída pelo delineamento de formas de complementaridade entre as duas formas de democracia, que contribuam para o aprofundamento de ambas. Para o autor, nessa complementaridade das duas democracias reside um dos caminhos da reinvenção da emancipação social.

Nessa mesma linha de pensamento, Bovero (2002) entende que a democracia representativa e participativa não são formas contrapostas uma à outra. Para o autor, diante da impossibilidade de pleno exercício da democracia direta no Estado brasileiro contemporâneo, em virtude, por exemplo, do vasto território, da elevada população e da complexidade dos problemas em debate, é mais interessante estabelecer entre ambas uma relação de complementaridade. É uma proposta que ameniza determinadas mazelas da democracia representativa e cria condições de maior e melhor exercício dos instrumentos participativos da democracia direta. A democracia participativa surge, portanto, em face dos problemas enfrentados pela democracia representativa, para reforçar os controles sobre a atuação estatal.

Como o próprio nome revela, a democracia participativa baseia-se na abertura do Estado a uma participação popular maior do que admitida no sistema da democracia puramente representativa. Para tanto, a democracia participativa conta com instrumentos 
institucionais novos, como a iniciativa popular e o referendo, que alteram significativamente o relacionamento entre Estado e sociedade (PEREZ, 2004).

Perez (2004) sustenta que a participação popular nunca foi colocada em tão grande relevo na ordem dos pré-requisitos para a efetiva realização da democracia como é nos dias atuais. Para Silva (1988 apud Perez, 2004, p. 34), “a democracia participativa está definitivamente ligada ao chamado Estado Democrático de Direito”:

\begin{abstract}
A Democracia que o Estado Democrático de Direito realiza há de ser um processo de convivência social numa sociedade livre, justa e solidária. ...em que o poder emana do povo, que deve ser exercido em proveito do povo, diretamente ou por representantes eleitos...; participativa, porque envolve a participação crescente do povo no processo decisório e na formação dos atos de governo; pluralista, porque respeita a pluralidade de idéias, culturas e etnias e pressupõe assim o diálogo entre opiniões e pensamentos divergentes da sociedade; há de ser um processo de liberação da pessoa humana das formas de opressão que não depende apenas do reconhecimento formal de certos direitos individuais, políticos e sociais, mas especificamente da vigência de condições econômicas suscetíveis de favorecer o seu pleno exercício (SILVA, 1988 apud Perez, 2004, p. 34).
\end{abstract}

Silva (1988 apud PEREZ, 2004), defende que a participação na administração é fruto do avanço social dos ideais democráticos, que superam hoje a esfera das relações meramente políticas para abranger toda uma diversidade de relações.

Nessa visão, Perez (2004) também sustenta que a participação se trata da democracia no sentido de adoção de instrumentos que interferem no modelo de atuar da administração, de maneira a torná-la mais aberta à influência externa. Para o autor, pode-se extrair do princípio democrático não somente a obrigação do Estado de respeitar as mais elementares normas da democracia representativa, como também, interfere na estruturação de processos que oferecem aos cidadãos efetivas possibilidades de aprender a democracia, participar nos processos de decisão e exercer o controle crítico na divergência de opiniões, concluindo-se que a construção da democracia participativa exige a convivência da representação política com mecanismos de participação popular na vida política.

Uma cultura, portanto, pode ser considerada democrática quando a sociedade é dirigida por valores de igualdade e de liberdade, que se expressam na compreensão e na aceitação do outro, no respeito aos direitos individuais e coletivos e no cumprimento dos seus deveres na vida pública e política (COELHO, 2007). 


\subsection{Política e esfera pública: democracia fortalecida}

Democracia remete diretamente ao exercício da política, a qual se referencia na atividade cívica do cidadão que se relaciona com a coisa pública e tem direito de exercer controle e vigilância sobre ela. A política é ação que permite o compartilhamento do poder de governar, tendencialmente centrado nas democracias representativas na figura do Estado de direito. Segundo Arendt (2006), a idéia de política e de coisa pública surge pela primeira vez na polis grega considerada o berço da democracia. Para a autora, o sentido da política é a liberdade. Utilizando o conceito grego da palavra política, Arendt diz que a política é baseada no fato da pluralidade dos homens, portanto, ela deve organizar e regular o convívio dos diferentes e não dos iguais. Dallari (2004, p. 10) define a política como “a conjugação das ações de indivíduos e grupos humanos, dirigindo-as a um fim comum”.

Conforme Arendt (2006), para os antigos gregos não havia distinção entre política e liberdade e as duas estavam associadas à capacidade do homem de agir em público, como forma de organização política. O homem moderno, muitas vezes, não consegue se envolver pelo ethos público em virtude de desilusões em relação ao político profissional e sua atuação no poder central. Arendt, porém, acreditava na ação do homem e na sua capacidade de fazer o improvável e o incalculável. A ação humana movida pelo ethos cívico torna possível mudar o rumo das determinações políticas e sociais, posto que “... sempre que os homens se juntam, move-se o mundo entre eles, e nesse interespaço ocorrem e fazem-se todos os assuntos humanos” (ARENDT, 2006, p. 36).

Arendt (2006; 2007) postula que a política é relacional e depende da dimensão espacial que se manifesta na convivência entre os homens. Nesse sentido, a autora alemã se refere ao exercício da política na esfera pública, lugar do debate público, de trocas intersubjetivas a partir do diálogo, locus que assume seus atributos mais autênticos e autônomos quando prevalece sua dimensão política.

Na esfera política ${ }^{5}$, sob outra perspectiva, mas influenciada pelas formulações de Arendt, Mouffe (1996) defende que o caráter individual de satisfação das necessidades sociais tem levado a uma preocupação que é central no debate da cidadania. Hoje, o ponto crucial é como construir nas sociedades um sentimento de pertencimento, de identidade, no qual os seus integrantes se reconheçam e se sintam integrados. Mouffe entende que depois que o

\footnotetext{
${ }^{5}$ Entende-se por esfera política a dimensão da expressão da liberdade humana no nível coletivo. É a esfera da decisão e do fazer no que diz respeito à melhor forma de condução da vida coletiva de um grupo, entidade, nação, em vista do bem-viver de seus integrantes (SCHÜTZ, 2004)
} 
cidadão aceitar a necessidade do político e a impossibilidade de um mundo sem antagonismos, será necessário encarar a forma como se poderá criar ou manter uma ordem democrática pluralista nessas condições.

Para Mouffe (1996), a identidade política é fundamental e a tentativa de constituir identidades para os cidadãos é uma tarefa importante da política democrática. Existem, no entanto, muitas concepções diferentes de cidadania e no seu concurso estão em jogo muitas questões vitais. Mouffe defende que a forma como definimos a cidadania está intimamente ligada ao tipo de sociedade e de comunidade política que desejamos.

A política, para Arendt (2006), como vimos, é uma necessidade imperiosa para a vida humana, tanto para a vida do indivíduo como para a sociedade. A autora defendia que, como o homem não é autárquico, mas depende de outros em sua existência, precisa haver um provimento da vida relativo a todos, sem o qual não seria possível o convívio. Para a autora, a garantia da vida no sentido mais amplo, portanto, é o objetivo e a tarefa da política, que está diretamente relacionada com a grande aspiração do homem moderno, que é a busca da felicidade.

Mouffe (1996), próxima à concepção arendtiana da política pautada na pluralidade dos homens, pressuposto da convivência entre diferentes, entende que deve haver o espaço para o pluralismo de culturas, formas coletivas de vida e regimes, bem como para o pluralismo de sujeitos, opções individuais e concepções do bem, o que tem conseqüências extremamente importantes na política. Para a autora, no reino da política a indeterminação não pode ter a última palavra, posto que a política exige decisão e qualquer tipo de regime político consiste no estabelecimento de uma hierarquia entre valores políticos e o exercício da cidadania.

Arendt (2006), por sua vez, entendia que o ser político, o viver numa 'polis', significava que tudo era decidido por palavras e convencimento, e não por meio de força ou violência. Para ela, ser livre significava não comandar, nem estar sujeito ao comando de outro.

Discutir a questão da política, nos termos de Arendt, nos dias atuais, como faz Mouffe, se traduz em grande desafio, visto que o cidadão está imbuído de desconfianças em relação aos homens públicos que nos representam no Parlamento. Mas, como nos lembra a própria Arendt (2006), o homem é um ser capaz de fazer política, desde que viva em sociedade e interaja com o outro, reconhecendo-o como igual, e desfrute do acesso a todos os direitos e seja respeitado em sua singularidade cognitiva e criativa. Todas as ações do homem são políticas e motivadas por decisões ideológicas. Tudo que se faz na vida, portanto, tem 
conseqüências e as pessoas são responsáveis por suas ações. A omissão, em qualquer aspecto da vida, significa deixar que uns escolham pelos outros.

A ação política de cada um está presente em todos os momentos, seja nos aspecto privado ou público de sua vida cotidiana. Vivendo-se com a família, relacionando-se com as pessoas no local onde mora, no trabalho, na escola, todos são partes integrantes da cidade, pertencente a um Estado e a um país, no qual cada um influencia em tudo o que acontece à sua volta. Pode-se participar da associação do bairro ou fazer parte de uma pastoral ou trabalhar como voluntário em uma causa em que se acredita. Pode-se votar em um político corrupto ou votar em um bom político. Em uma democracia, o homem é livre para agir.

Não se pode, no entanto, entender erroneamente que política se restringe simplesmente ao ato de votar. Faz-se política quando se toma atitudes no trabalho, quando há uma conversa em uma mesa de restaurante ou em uma confraternização. A política se faz quando são exigidos os direitos do consumidor, quando o cidadão se mostra indignado ao ver crianças fora das escolas, sendo massacradas nas ruas, quando se exige os direitos dos cidadãos, quando se interessa pelo progresso da nação. Por todos esses aspectos, a política está presente diariamente na vida do cidadão. Atitudes e omissões, portanto, fazem parte da ação política perante a vida. No sentido grego da palavra "política”, o cidadão é "responsável politicamente” pela luta por justiça social e uma sociedade verdadeiramente democrática e para todos.

Arendt (2006) defendia que ser visto e ouvido por outras pessoas é muito importante, pelo fato de que todos vêem e ouvem sob ângulos diferentes e este é o significado da vida pública. Para pertencer à comunidade política, conforme Mouffe (1996), o que é exigido é que se aceite uma linguagem específica da relação civil, a res publica. Essas regras prescrevem normas de conduta que devem ser subscritas na procura de satisfações escolhidas e na execução de ações também escolhidas. A identificação com essas regras da relação civil cria uma identidade política comum entre pessoas que, de outra forma, estariam empenhadas em empreendimentos diversos.

Se entendermos a cidadania como uma identidade política, criada por meio da identificação com a res publica, torna-se possível uma nova concepção de cidadão. A definição de cidadão se altera, visto que agora a ênfase é colocada na identificação com a res publica, uma identidade política comum de pessoas que podem estar empenhadas em muitos empreendimentos com finalidades diferentes e com diversas concepções de bem, mas que, na procura da sua satisfação e na execução das suas ações, aceitam se submeter às regras 
prescritas pela res publica. O que as liga, portanto, é o reconhecimento de valores éticospolíticos (MOUFFE, 1996).

Mouffe (1996) depreende que a distinção entre o privado e o público é mantida, tal como a distinção entre o indivíduo e o cidadão, mas não correspondem a esferas discretas e separadas. Para a autora, não se pode dizer:

... aqui terminam os meus deveres como cidadão e começa a minha liberdade como indivíduo. Estas duas identidades existem numa tensão permanente, que nunca pode ser conciliada. Mas é precisamente a tensão entre a liberdade e a igualdade que caracteriza a democracia moderna (MOUFFE, 1996, p. 99).

Todas as situações numa sociedade, conforme Mouffe (1996), são um encontro entre o público e o privado, entre uma ação e um discurso, para obter uma satisfação substantiva imaginada ou desejada. E nenhuma situação implica a exclusão de qualquer outra. As escolhas, as decisões e os desejos são privados, posto que estão sob a responsabilidade de cada indivíduo, porém os desempenhos são públicos, porque se exige que estejam sujeitos a condições especificadas na res publica.

Portanto, entendendo-se que a identidade política foi criada por meio da identificação com a res publica, conforme o próprio sentido grego da palavra política, ela é baseada na pluralidade dos homens e deve organizar e regular o convívio dos diferentes, contribuindo, dessa forma, para que esteja sempre presente a prática da democracia e da cidadania.

Em reflexão ao que foi discutido por Arendt e Mouffe, infere-se que o cidadão sente necessidade de ser visto e ouvido por outras pessoas e de participar de grupos de interesse, criando identificação com as regras da relação civil e uma identidade política comum em prol da coisa pública, por meio dos espaços públicos que tornam possível o controle social sobre a mesma.

\subsection{Espaços públicos e controle social sobre a coisa pública: o papel dos conselhos no quadro democrático}

Na mesma linha de pensamento de Arendt (2006) e Mouffe (1996), Dagnino (2002) entende que o encontro de articulação entre os agentes políticos e sociais, por meio dos espaços públicos, é condição necessária e fundamental para o resgate da legitimidade do Estado, que deve aperfeiçoar seus instrumentos de governabilidade e criar novas estruturas de 
governança, a fim de estimular a participação da cidadania nos moldes de uma democracia associativa.

Nesse aspecto, Dagnino (2002) considera como espaços públicos, no sentido de esfera pública, os conselhos, os fóruns de debate, as câmaras setoriais, os orçamentos participativos, entre outras relações de encontro entre a sociedade civil e o governo, visando maior transparência e publicização das políticas públicas e a formulação de agendas que venham a se tornar públicas. Dessa forma, a autora sustenta que existem vários espaços com diferentes propósitos, que vão desde os formalizados e estáveis, que exercem funções consultivas e/ou deliberativas com respeito às políticas públicas, até os espaços de encontros específicos, que se destinam à execução dessas políticas e, ainda, os espaços de relações que se estruturam a partir da sociedade civil e que objetivam a articulação de vários setores, a fim de exercer pressão e monitoramento sobre a atuação do Estado.

Esses espaços públicos, conforme Teixeira (2002), apesar de todas as dificuldades enfrentadas, foram conquistas de movimentos sociais, cujos integrantes lutaram para que as suas demandas fossem incorporadas nas políticas governamentais. Foram, também, a forma de abertura de governo e tentativa de construção de uma gestão pública mais democrática.

O conceito de espaço público e controle público remetem ao significado de controle social, que, no sentido amplo, pode ser definido como a capacidade da sociedade civil em interferir nas políticas públicas, interagindo com o Estado na definição de prioridades e na elaboração dos planos de ação dos municípios, dos estados ou do governo federal, avaliando objetivos, acompanhando a implementação de metas e programas e avaliando os processos de resultados (BRASIL, Ministério da Saúde, 1998).

Conforme Leal (2001), o tema controle social está em grande evidência nas discussões sociológicas e políticas sobre os parâmetros da reforma do Estado nas sociedades contemporâneas. A autora afirma que as discussões têm sido realizadas em torno da importância do cidadão se integrar aos processos decisórios, com atuação politicamente ativa e dotado de conhecimento para participar de debates públicos.

O controle social, para Leal (2001), é uma forma de aumentar a capacidade de influência da sociedade sobre o Estado; é a conformação de uma autoridade, com base na coletividade, fundada democraticamente para regular tanto o ente estatal, como o mercado e a própria sociedade. Leal entende que a base da formação do controle social é a cidadania, visto que ela habilita o indivíduo à ação racional e reúne princípios de democracia, sociedade pluralista, educação política e iniciativa. 
Para a autora, a resposta óbvia para a indagação de quais sujeitos sociais são habilitados para exercer o controle social seria a própria sociedade. No entanto, ela entende que essa seria uma resposta muito generalizada, posto que a interpelação é abstrata e, ainda, a identificação da sociedade com a democracia e a igualdade não se dão de forma mecânica.

Outra resposta possível seria o cidadão diretamente interessado nos resultados de certa ação estatal, mas o controle social não pode ficar circunscrito apenas aos cidadãos diretamente envolvidos. Uma terceira resposta poderia ser as organizações sociais permanentes. A importância dessas organizações como sujeito do controle social tem se destacado muito, tanto na teoria como na prática, mas colocá-las como responsáveis pelo exercício do controle social iria supor a exclusão de atores individuais e dos segmentos da sociedade, que, embora não tenham capacidade de organização, têm interesses públicos para exercer esse controle (GRAU, 2006).

Pereira (1997), por sua vez, entende que há três mecanismos de controle fundamentais, que são o Estado, o mercado e a sociedade civil. Para ele, o Estado mantém o sistema legal ou jurídico, com os princípios básicos para que os demais mecanismos funcionem; o mercado é o sistema econômico, no qual o controle se realiza por meio da competição; e a sociedade civil organizada em grupos sociais, pela qual o controle se dá na defesa dos interesses particulares ou interesses públicos.

Nessa defesa dos interesses públicos, surgem os conselhos de controle e acompanhamento das políticas do Estado. Esses conselhos têm se tornado um forte espaço de controle social, mesmo diante das dificuldades encontradas pela sociedade civil e pelos movimentos sociais para a ocupação de forma propositiva desses espaços públicos e diante das dificuldades de mudanças culturais da gestão pública.

Os conselhos são espaços públicos de interface entre o Estado e a sociedade, pontes entre a população e o governo, assumindo a co-gestão das políticas públicas, por meio do qual o poder é partilhado entre os representantes do governo e da sociedade e onde todos assumem o papel de propor, negociar, decidir, implementar e fiscalizar a realização do interesse público.

Avritzer (2000, p. 18) afirma que os conselhos são “instituições híbridas”, na medida em que são “formadas em parte por representantes do Estado, em parte por representantes da sociedade civil, com poderes consultivos e/ou deliberativos, que reúnem, a um só tempo, elementos da democracia representativa e da democracia direta”.

Tatagiba (2002) questiona sobre qual seria o lugar dos conselhos na nova institucionalidade da forma de governar. Para ela, a constituição de conselhos gestores é um 
passo importante na democratização do processo decisório no interior do aparelho estatal, mas afirma que pesquisas demonstram ser uma tarefa difícil modificar a dinâmica de funcionamento dos conselhos, na medida em que o Estado ainda é o protagonista central na definição da agenda da política pública.

Esses mecanismos sociais, atores do espaço público não estatal, possuem finalidades e funcionamento diversos dos partidos políticos. Os dois, portanto, são organizações políticas, que possuem entre si relações de interdependência e complementaridade. Sua atuação conjunta fortalece o processo democrático e traz a redefinição do Estado, que passa a ser mais atuante nas respostas às demandas sociais que lhe apresenta.

Nessa perspectiva, controle social também está vinculado a uma forma de regulação e fiscalização do ambiente decisório, cujo interesse coletivo esteja em jogo. Nos termos de Grau (2006), o interesse público não existe de forma absoluta e, portanto, autoritária. Ele existe de forma relativa, mediante o consenso que se vai formando sobre o que constitui um certo moral comum. Esse consenso, conforme a autora, parte de uma diferenciação entre o auto-interesse e os valores cívicos como fatores determinantes de motivação humana.

O controle social, conforme Dropa (2003), é um avanço na construção de uma sociedade democrática e que determina alterações profundas nas formas de relação do Estado com o cidadão. Ele afirma que a reforma e modernização do Estado possibilita a criação de mecanismos capazes de viabilizar a integração dos cidadãos no processo de definição, implementação e avaliação da ação pública.

Dropa (2003) depreende que a partir de um crescente estabelecimento do controle social será possível garantir serviços de qualidade, pois a partir do momento em que o Estado deixa de participar diretamente na prestação de serviços públicos, passando apenas a promovê-los e gerenciá-los, ele buscará ao mesmo tempo, o controle social e a participação da sociedade na gestão da coisa pública. Há, no entanto, para Aguillar (1999), uma marcada tensão entre o controle exercido pelo Estado e pela sociedade (controle social). A mais evidente é aquela que se manifesta no sentido de que a ausência absoluta de controle estatal representa a hipótese em que o controle social será o mais intenso possível e, por outro lado, quanto maior for o grau de concentração regulatória do Estado, menor será a capacidade do controle social das atividades. Dessa forma, conforme Aguillar (1999), surgem diversas questões fundamentais para o tema controle social, como a forma como esse controle pode ser desempenhado satisfatoriamente; se ele deve ser implementado por via jurídica ou não, suscitando o aparente paradoxo do controle social pela via do controle estatal; a capacidade 
dos atuais mecanismos jurídicos para permitir o efetivo controle social e as limitações que o desenvolvimento tecnológico origina no exercício da participação popular.

Grau (2006), com base em uma revisão de literatura sobre o tema, deduz que diversos estudiosos, como Gagne, Quirk, Pradhan, Shah, Picciotto, entre outros, expressam a necessidade do controle social sobre a administração pública, porém, a autora conclui que praticamente não existem indicações sobre “como” tornar o controle possível, nem sobre “o que” e “quais” sujeitos sociais são habilitados para exercer esse controle social (GRAU, 2006, p. 270).

Mesmo com todas essas questões, o tópico seguinte evidenciará como a ampliação desses canais de participação potencializa alterações na cultura política, especificamente na cultura política brasileira, colaborando para o processo de maximização da democracia no seio social, posto que além do direito do voto e da liberdade para integrar quadros partidários, o cidadão pode ainda fazer uso de mecanismos de participação em políticas públicas, atuando de maneira individual ou coletiva no controle social.

\subsection{A conquista da cidadania no Brasil: uma reflexão sobre política, democracia e esfera pública brasileiras}

A identidade política comum e o sentido de pertencimento a uma comunidade política é o real significado da cidadania, que não é simplesmente um conjunto de direitos e responsabilidades. Ela vai além desse conceito, envolvendo uma cidadania ativa no sentido forte do termo, que expressa o direito a ter direitos de forma igualitária, na definição e invenção de uma nova sociedade (DAGNINO, 2002).

O tema "cidadania” passou a ser mais discutido no mundo contemporâneo, sobretudo após períodos de pós-guerra, no século passado, inclusive no Brasil, sendo assunto de debate freqüente entre os mais variados segmentos sociais. Entretanto, nem sempre foi assim. A concepção atual carrega resquícios históricos dessas mudanças e implica nas questões atuais de desenvolvimento.

A origem do conceito de cidadania, do ponto de vista filosófico, foi baseada em Hobbes no final do século XVI e em Rousseau no século XVII (LUCA, 2003). Conforme Carvalho (2004), embora o fenômeno da cidadania seja historicamente definido, ele é muito complexo. Janoski (1998 apud VIEIRA, 2001), define as três correntes teóricas de estudos sobre os fenômenos da cidadania que são a teoria de Marx e Gramsci a respeito de sociedade 
civil; a abordagem de Tocqueville/Durkheim, sobre cultura cívica; e a teoria de Marshall (1967), acerca dos direitos de cidadania.

De acordo com Marshall (1967), a cidadania moderna se desenvolveu pioneiramente na Inglaterra, com a introdução dos direitos civis no século XVIII, dos direitos políticos no século XIX e dos direitos sociais no século XX. Marshall define os direitos civis como os direitos individuais de liberdade, igualdade, direito de ir e vir, direito à vida e à segurança. Os direitos políticos, para ele, são os direitos individuais exercidos coletivamente e dizem respeito à liberdade de associações e de reunião, de organização política e sindical, à participação política e eleitoral e ao sufrágio universal. Já os direitos sociais são os direitos ao trabalho, saúde, educação, aposentadoria e ao acesso aos meios materiais de vida e bem estar social.

No contexto brasileiro, no entanto, os caminhos para se chegar à cidadania foram diferentes daqueles percorridos pelos ingleses nos séculos XVIII, XIX e XX, conforme especificou Marshall (1967). A conquista da cidadania no Brasil trilhou caminhos tortuosos, com avanços e retrocessos, nos levando a um percurso de muitos anos para a alcançarmos (CARVALHO, 2004). O conceito só se tornou “materializado”, de fato, após a promulgação da Constituição Federal de 1988, quando passou a fazer parte do nosso cotidiano, especialmente por estar vinculada à concepção de participação social nas políticas públicas.

Segundo Carvalho (2004), à época da independência do Brasil, não havia cidadãos brasileiros nem pátria brasileira. Havia, sim, a escravidão, que era o fator mais negativo para o exercício da cidadania civil e que, juntamente com as grandes propriedades e o comprometimento do poder público com o poder privado, não constituía ambiente favorável para formação de futuros cidadãos. Dessa forma, não havia república no Brasil e nem sociedade política. Os direitos civis beneficiavam a poucos, os direitos políticos a pouquíssimos e os direitos sociais ainda não eram conhecidos, pois a assistência social ficava a cargo da igreja e de particulares. Nesse período, os valores da liberdade individual, base dos direitos civis, não tinham grande peso no Brasil. Entretanto, após um longo período de luta contra a escravidão, surgiu o movimento popular abolicionista, que conquistou a abolição em 1888.

Já os direitos políticos avançaram, posto que em 1824 foi outorgada a Constituição que regeu o país até o fim da monarquia. Essa Constituição estabeleceu os três poderes tradicionais: o executivo, o legislativo e o judiciário; regulou os direitos políticos e definiu que os homens com idade igual ou maior que 25 anos poderiam votar e ser votados (CARVALHO, 2004). 
Quanto aos direitos sociais, Carvalho (2004) assegura que a assistência social estava quase exclusivamente nas mãos de associações particulares e de irmandades religiosas oriundas do colonialismo. A Constituição republicana de 1891 retirou do Estado a obrigação de fornecer educação primária, constante da Constituição de 1824 e proibiu a interferência do governo federal na regulamentação do trabalho. Só em 1926 é que o governo federal foi autorizado a legislar sobre o trabalho, regulando o direito de férias. Em outubro de 1930 aconteceu um marco histórico para a cidadania, quando foi deposto o então presidente da República, finalizando assim a Primeira República.

Conforme depreende Carvalho (2004), o ano de 1930 foi um divisor de águas na história do país, já que a partir dessa data houve aceleração das mudanças sociais e políticas. No período de 1930 a 1937 o Brasil viveu uma fase de grande agitação nos direitos políticos. Pela primeira vez foram criados movimentos políticos de massa de âmbito nacional e foi dedicada grande atenção ao problema trabalhista e social, culminando na Consolidação das Leis do Trabalho, de 1943. As eleições de 1933 introduziram conquistas democráticas e avanço na cidadania política, pela introdução do voto secreto, criação da justiça eleitoral e ganho do direito ao voto às mulheres, pela primeira vez.

De 1937 a 1945 o país viveu sob um período crítico, com o regime ditatorial civil, garantido pelas forças armadas, quando as manifestações políticas eram proibidas, o governo legislava por decreto, a censura controlava a imprensa e os cárceres se enchiam de inimigos do regime. A despeito desses problemas, no período de 1930 a 1945 foi implantada a base da legislação trabalhista e previdenciária, que depois seria apenas aperfeiçoada e ampliada para um número maior de trabalhadores (CARVALHO, 2004).

Em 1946 foi promulgada uma nova Constituição, que manteve as conquistas sociais do período anterior e garantiu os tradicionais direitos civis e políticos. O país entrou, então, na fase da primeira experiência democrática de sua história. Houve liberdade de imprensa e de organização política. O voto foi estendido a todos os cidadãos, homens e mulheres, com mais de 18 anos de idade.

A partir de 1945 a participação do povo na política cresceu significativamente, tanto pelo lado das eleições como da ação política organizada em partidos, sindicatos, ligas camponesas e outras associações. Foi esse o primeiro período da história brasileira em que houve partidos nacionais de massa.

Em 1974 começou a abertura, quando o então presidente permitiu eleições diretas para governadores de estados. Como ato final da transição, os militares se abstiveram de impor um general como candidato à sucessão presidencial de 1985 e uma coalizão de forças da oposição 
e do partido do governo levou à vitória do candidato oposicionista, marcando, assim, o final do período de governos militares e a eleição do primeiro presidente civil no Brasil.

Com o final da ditadura militar, o Brasil passou por um período de "redemocratização" (OLIVEIRA, 2003). Houve uma maior participação política da sociedade e, conseqüentemente, avanços na democratização do Estado e fortalecimento da sociedade civil. O marco principal do período de transição entre a ditadura e a democracia foi a promulgação da Constituição Federal de 1988, que contemplou os direitos sociais e os direitos e deveres individuais e coletivos e, ainda, estabeleceu a universalização do voto e a liberdade de criação de partidos políticos. Com isso, foi retomada a supremacia civil, por meio da constituinte de 1988, que redigiu e aprovou a constituição mais liberal e democrática do país, merecendo por isso o nome de Constituição Cidadã (CARVALHO, 2004).

Por meio dessa Constituição, os direitos políticos se expandiram e houve a realização da primeira eleição direta para presidente da República em 1989 e o afastamento desse presidente dois anos depois, pela mesma população que há oito anos antes pedia as eleições diretas para presidente, confirmando, dessa maneira, a democratização do país.

A partir de 1994, quando foram implantadas as primeiras medidas de estabilização da economia, houve muitas reformas, dentre elas a privatização das empresas estatais, alterações na Previdência Social, a Reforma do Estado e a regulamentação da concessão de serviços públicos para a iniciativa privada (LUCA, 2003). Na visão de Luca (2003), a orientação neoliberal, no entanto, voltada para o mercado, prevê uma diminuição do papel ativo do Estado em todos os setores, exigindo uma sociedade civil preparada para participar ativamente das políticas públicas, que fomenta a construção de uma cidadania efetiva.

Essa redefinição da noção de cidadania apontou na direção de uma sociedade mais igualitária e de participação na gestão pública, que pudesse assegurar as condições de existência da sociedade civil e a vigência de um conjunto de direitos. Uma conseqüência disso foi a construção de canais de interlocução entre o Estado e a sociedade civil para promover o debate entre os agentes ou como forma de ampliação e democratização da gestão estatal.

No entanto, o fato da teoria social recuperar o sujeito histórico, não assegura que ele venha, por si só, tomar a iniciativa de assumir este estado de cidadania plena, posto que, de certo modo, ainda ecoa, por um lado, a crença liberal no individualismo, voltado agora para questões coletivistas e, por outro lado, o pressuposto de um voluntarismo político tópico do pensamento crítico (LEAL; RIBEIRO, 2002).

Conforme as autoras (2002), as respostas encontradas nos graves problemas sociais provocados pela hegemonia no mercado tendem a encontrar alternativas por meio de ativação 
da sociedade civil, conferindo-lhe atributos, deveres cívicos, competências e responsabilidades públicas que a aproximam do Estado, como se o Estado, aliado a ela, pudesse enfrentar com mais isenção as demandas sistêmicas.

No caso do Brasil, pode-se observar que as atuais políticas públicas de educação, além de inserirem a noção de controle público em âmbitos setoriais de suas estruturas executivas, ainda o fazem de modo a inibir o efetivo controle do público sobre elas. Quase sempre, instrumentos normativos são criados sem que tenham resultado de movimentos e apelos por grupos e setores organizados da sociedade.

Outro problema apontado por Leal e Ribeiro (2002) é que a representação política no Brasil historicamente se configurou como um sistema com regras singulares, não vinculadas diretamente ao exercício do voto, esvaziando até mesmo o conceito de cidadania como categoria político-jurídica. Para elas, quando o Estado, na atual conjuntura, cria noções de controle público e cidadania em seus estatutos jurídicos, não é encontrada uma cultura cívica e política que corresponda à expectativa desta normatividade. Dessa forma, surge a discussão acerca da natureza e finalidade desses instrumentos de participação cidadã, questionando-se até que ponto esses instrumentos são resultados de um patriarcalismo historicamente marcante das políticas estatais brasileiras ou até que ponto eles são manifestações efêmeras, oriundas da intervenção de setores organizados da sociedade civil brasileira.

A discussão levantada sobre as formas dos cidadãos exercerem a participação cidadã, com função reguladora sobre a esfera pública, se depara nos instrumentos da democracia direta e na eficácia e efetividade desses instrumentos para promover o controle social do que pertence e interessa ao público. Para tanto, é necessária a criação de uma estrutura de oportunidades de participação cidadã que permita o controle de políticas e decisões públicas. Entretanto, para que haja a conformação do sujeito em cidadão e para que esse cidadão conheça seu status social e político como tal, é necessário que se forme um público consciente de seus direitos e potencialidades de participação na administração e nos processos decisórios (LEAL; RIBEIRO, 2002).

\subsection{O exercício da democracia participativa no Brasil por meio do controle social}

A despeito de todas as dificuldades, o controle social no Brasil, realizado por meio dos espaços públicos, conquistados com a nova definição da noção de cidadania, pressupõe um avanço na construção de uma sociedade democrática, que determina alterações profundas nas formas de relação do Estado com o cidadão. Com a reforma e modernização do Estado 
brasileiro, mediante a Constituição Federal de 1988, tornou-se possível se criar mecanismos capazes de viabilizar integração dos cidadãos no processo de definição, implementação e avaliação das políticas públicas. Esse avanço traz fortalecimento gradativo de mecanismos que privilegiam a participação popular, tanto na formulação quanto na avaliação de políticas públicas, viabilizando o controle social das mesmas.

Até o fim da ditadura militar não se falava em controle social no Brasil, pois o autoritarismo e participação popular são termos antagônicos. Somente com o início do processo de redemocratização do país, a partir do fim do governo militar, na década de 80 é que a expressão “controle social” passou a ser utilizada (DROPA, 2003).

Após esse período da ditadura, o Estado brasileiro tornou-se mais próximo do cidadão e passou por um processo de democratização e a exercer seu novo papel de construção de relações sociais e políticas com a sociedade. A partir daí, surgiu a real possibilidade de uma interação do Estado com a sociedade civil $^{6}$ organizada que passou a assumir sua função de intermediação entre a comunidade, o mercado e o Estado e a ser agente social real. Dessa forma, a sociedade civil começou a desempenhar um papel ativo nesse processo e a fomentar as reformas institucionais estatais e do mercado. Como resultado, houve um fortalecimento da cidadania (PEREIRA, 1999). Com esse fortalecimento, a sociedade civil vem adquirindo um papel determinante nas políticas públicas. O cidadão como sujeito ativo, pressiona em direção a determinadas ações e opções de planos e projetos que produzem, conseqüentemente, estruturas institucionais que favorecem a cidadania, oportunizando a própria democracia.

A promulgação da Constituição Federal de 1988 é um resultado dessa influência da sociedade civil nas políticas públicas e por meio dela evoluíram os conceitos que contemplavam a necessidade de melhor gestão dos recursos públicos e da necessidade de melhor controle da sociedade sobre a formulação de políticas e de ações da coisa pública. Nesse momento, o controle social foi incorporado com maior ênfase ao debate, procurando-se estabelecer espaços para a participação das entidades classistas, dos movimentos populares, dos sindicatos e da população, entre outros, de tal forma que permitisse o exercício da cidadania em um quadro de aprofundamento do ambiente democrático. Com isso, conforme Leal (2001), nos dias atuais há um nítido desenvolvimento da sociedade civil para recuperar e consolidar o cidadão como sujeito político e a discussão sobre sociedade civil é muito apropriada para se considerar um controle público-social, posto que o ressurgimento do seu conceito é um tema debatido por muitos autores, estudiosos do assunto.

6 Sociedade civil, na perspectiva deste trabalho se refere às organizações e instituições cívicas voluntárias que formam a base de uma sociedade em funcionamento, na co-gestão da coisa pública. 
Essa Carta Magna traz dispositivos que contemplam os direitos dos cidadãos e ampliam a participação da sociedade civil nas políticas públicas, dispondo em seu bojo do instituto do controle social e da participação popular, considerada como o poder de influenciar diretamente nas políticas públicas. Alguns dispositivos infraconstitucionais também legislam sobre esse assunto, como a lei 8.987 - Lei de concessões, que estabelece diversas medidas para viabilizar o controle por meio da sociedade; e a lei 8.078 - Código do consumidor, que dispõe sobre os princípios e obrigações a serem seguidos para assegurar aos consumidores um maior controle dos serviços públicos essenciais.

Simultaneamente aos dispositivos legais que introduziram mecanismos de exercício da cidadania, a sociedade passou a ser mais exigente quanto à maior transparência nas ações da administração pública e essa é uma conquista obtida pelo desenvolvimento da sociedade civil, como uma das expressões maiores da democracia, onde o cidadão passa a ser fundamental no processo de avaliação das ações públicas. O controle social, portanto, é uma forma de se estabelecer uma parceria eficaz e gerar a partir dela um compromisso entre poder público e população, capaz de garantir a construção de saídas para o desenvolvimento econômico e social do país.

Paralelamente à exigência da sociedade, a necessidade de financiamentos de recursos por parte dos estados junto a organismos nacionais e internacionais trouxe também, no bojo dos contratos e convênios, cláusulas destinadas à necessidade de maior transparência da gestão dos recursos financiados e da gestão de uma forma em geral.

Com essa evolução, tanto da sociedade, quanto do poder público, por todas as partes do Brasil é possível perceber comunidades se organizando na defesa de seus interesses e trabalhando para diminuir ou corrigir desigualdades, mediante o acesso a bens e serviços que assegurem os seus direitos humanos fundamentais.

Essa organização da sociedade tem se dado por meio de conselhos gestores, que são espaços de gestão da coisa pública e, no entender de Arendt (1973 apud Gohn, 2000) são a única forma possível de um governo horizontal, um governo que tenha como condição de existência a participação e a cidadania.

Conforme Gohn (2000, p. 176), pode-se relembrar algumas experiências referentes a conselhos nas últimas décadas:

os conselhos comunitários, criados para atuarem junto à administração municipal ao final dos anos 70 (Gohn, 1990); os conselhos populares ao final dos anos 70 e parte dos anos 80 (URPLAN, 1984; Moura, 1988; Gohn, 1990), e os conselhos gestores institucionalizados... 
Nos anos 1990, afirma Gohn (2000), a grande novidade foram os conselhos gestores, que tinham caráter institucional, por terem o papel de serem instrumentos mediadores na relação sociedade/Estado e serem inscritos na Constituição de 1988 e em outras leis do país. Essa Constituição adotou como princípio geral a cidadania e previu instrumentos concretos para seu exercício, via democracia participativa. Dessa forma, diversas leis orgânicas passaram a regulamentar o direito constitucional à participação, por meio de conselhos deliberativos, de composição paritária entre representantes do poder executivo local e de instituições da sociedade civil. Desde então, um número crescente de estruturas colegiadas passou a ser exigência constitucional nos diversos níveis da administração pública, tanto federal, como estadual e municipal. Para Gohn (2000), com esses conselhos, gera-se um nova institucionalidade pública, posto que criam uma nova esfera social-pública. Eles são um novo padrão de relações entre Estado e sociedade, já que viabilizam a participação de segmentos sociais na formulação de políticas sociais e possibilitam à população o acesso aos espaços onde se tomam as decisões políticas de seu interesse. Esses colegiados criam condições para um sistema de vigilância sobre a gestão pública e implicam numa maior cobrança de prestação de contas por parte do poder executivo, principalmente no nível municipal.

No que concerne à educação, a Constituição Federal de 1988, com o objetivo de respaldar a adoção de institutos participativos na Administração Pública nessa área, determina em seu artigo 205 que a educação, direito de todos e dever do Estado e da família, será promovida e incentivada com a colaboração da sociedade, visando ao pleno desenvolvimento da pessoa e seu preparo para o exercício da cidadania. Já o inciso VI, do artigo 206, apresenta como um dos princípios a gestão democrática do ensino público.

A partir da concepção segundo a qual o ensino tem relevante papel na transformação social do país, a Carta Magna define a educação como um direito social, a ser assegurado com prioridade às crianças e aos adolescentes, estabelecendo que esse é um direito de todos e dever do Estado e da família, posto que pela educação passam a geração de empregos, a inclusão social, o desenvolvimento sustentado, a produção de conhecimento e a soberania da Nação.

O Ato das Disposições Constitucionais Transitórias, em seu art. 60, estabelece que o poder público desenvolverá esforços, com a mobilização de todos os setores organizados da sociedade, para eliminar o analfabetismo e universalizar o ensino fundamental.

Com base nas diretrizes normativas e constitucionais de 1988, nos últimos anos foram adotadas políticas públicas voltadas para uma visão sistêmica da educação básica, que 
privilegia todos os níveis e modalidades de ensino, sem distinção entre eles, caracterizandose, dessa forma, um grande avanço para educação básica pública brasileira. 


\section{O FUNDO DE MANUTENÇÃO E DESENVOLVIMENTO DA EDUCAÇÃO BÁSICA E DE VALORIZAÇÃO DOS PROFISSIONAIS DA EDUCAÇÃO (FUNDEB) E SEU CONSELHO DE ACOMPANHAMENTO E CONTROLE SOCIAL}

Uma das diretrizes constitucionais estabelecidas para o avanço da educação básica pública brasileira foi a criação do Fundeb, instituído para contribuir com a melhoria da qualidade na educação, tendo como foco todas as etapas e modalidades da educação básica, desde a creche até o ensino médio.

O Fundeb é um fundo de financiamento da educação básica pública, de natureza contábil e de âmbito estadual, composto por recursos dos próprios estados e municípios, complementados pela União, tendo como objetivo concorrer para a universalização da educação básica, promover a eqüidade, melhorar a qualidade do ensino e valorizar os profissionais da educação, proporcionando elevação e uma nova distribuição dos investimentos em educação, decorrentes de mudanças relacionadas às fontes financeiras que o formam, ao percentual e ao montante de recursos que o compõem, como também ao seu alcance. Foi instituído pela Emenda Constitucional n. ${ }^{\circ}$ 53, de 19 de dezembro de 2006 e regulamentado pela Medida Provisória $\mathrm{n}^{\circ}$ 339, de 28 de dezembro do mesmo ano, convertida na Lei $n^{0} 11.494$, de 20 de junho de 2007, e pelo Decreto $n^{\circ} 6.253$, de 13 de novembro de 2007 (BRASIL, MEC-FNDE, 2008).

Esse novo Fundo substituiu o Fundo de Manutenção e Desenvolvimento do Ensino Fundamental e de Valorização do Magistério (Fundef), que vigorou até o final de 2006 e atendia apenas o Ensino Fundamental nas modalidades regular e especial. O Fundeb, além de atender o ensino fundamental, a Educação Infantil, o Ensino Médio, atende também a Educação de Jovens e Adultos, promovendo a inclusão sócio-educacional no âmbito de toda a educação básica e oportunizando o acesso à educação àqueles que não o tiveram em sua infância.

Desde a promulgação da Constituição de 1988, 25\% das receitas dos impostos e transferências dos estados, Distrito Federal e municípios se encontram vinculados à Educação, conforme regulamenta seu art. 212. Com a Emenda Constitucional $n^{0} 14 / 96$, desses $25 \%$ de recursos da educação, 15\% passaram a ser sub-vinculados ao Ensino Fundamental, sendo que parte dessa sub-vinculação passava pelo Fundef, cuja partilha dos recursos, entre o Governo Estadual e seus Municípios, tinha como base o número de alunos do ensino fundamental atendidos em cada rede de ensino. 
Com a Emenda Constitucional n $n^{\circ}$ 53/2006, a sub-vinculação das receitas dos impostos e transferências dos estados, Distrito Federal e municípios passaram para 20\% e sua utilização foi ampliada para toda a Educação Básica, por meio do Fundeb, que promove a distribuição dos recursos com base no n. ${ }^{\circ}$ de alunos da educação básica, de acordo com dados do último Censo Escolar, sendo computados os alunos matriculados nos respectivos âmbitos de atuação prioritária, conforme art. 211 da Constituição Federal. Dessa forma, os Municípios receberão os recursos do Fundeb com base no número de alunos da educação infantil e do ensino fundamental e os governos estaduais com base nos alunos do ensino fundamental e médio. Da mesma forma, a aplicação desses recursos, pelos gestores estaduais e municipais, deve ser direcionada levando-se em consideração a responsabilidade constitucional que delimita a atuação dos estados e municípios em relação à educação básica. No caso do Distrito Federal, tanto para distribuição quanto para a aplicação dos recursos, a regra adotada é adaptada à especificidade prevista no Parágrafo Único, art. 10 da Lei n ${ }^{\circ}$ 9.394/96 - a Lei de Diretrizes e Bases da Educação, que estabelece a responsabilidade do governo distrital em relação a toda a educação básica.

A arrecadação dos recursos que compõem o Fundeb é realizada pela União e pelos Governos Estaduais e a disponibilização dos recursos gerados é realizada periodicamente, pelo Tesouro Nacional e pelos Órgãos Fazendários dos Governos Estaduais, ao Banco do Brasil, que procede a distribuição automática dos recursos mediante crédito em favor dos estados e municípios beneficiários, em conta única e específica instituída para essa finalidade, no próprio Banco do Brasil ou na Caixa Econômica Federal, conforme art. $1^{\circ}$ da Portaria 317 da Secretaria do Tesouro Nacional.

Essa distribuição, como já foi mencionado, é realizada com base no número de alunos da educação básica pública, de acordo com dados do último Censo Escolar, sendo computados os alunos matriculados nos respectivos âmbitos de atuação prioritária, conforme art. 211 da Constituição Federal.

Os créditos nas contas específicas do Fundeb de cada governo ocorrem na mesma periodicidade em que são creditados os valores das fontes “mães” alimentadoras do Fundo. Ou seja, são creditados na conta do Fundeb 20\% das seguintes fontes de impostos e transferências constitucionais: i) Fundo de Participação dos Estados (FPE); ii) Fundo de Participação dos Municípios (FPM); iii) Imposto sobre Circulação de Mercadorias e sobre prestação de Serviços (ICMS); iv) Imposto sobre Produtos Industrializados, proporcional às exportações (IPIexp); v) Imposto sobre Transmissão Causa Mortis e Doações de quaisquer bens ou direitos (ITCMD); vi) Imposto sobre a Propriedade de Veículos Automotores 
(IPVA); vii) Imposto sobre a Propriedade Territorial Rural - quota-parte dos Municípios (ITRm); viii) Recursos relativos à desoneração de exportações; ix) Arrecadação de imposto que a União eventualmente instituir no exercício de sua competência (quotas-parte dos estados, Distrito Federal e municípios); e x) Receita da dívida ativa tributária, juros e multas, relativas aos impostos acima relacionados.

Além desses recursos, integram a composição do Fundeb, a título de complementação financeira, recursos federais, com o objetivo de assegurar valor mínimo nacional por aluno/ano, no âmbito de cada Fundo, nos estados e Distrito Federal onde este limite mínimo não é alcançado com os recursos dos próprios governos sub-nacionais. O total repassado em um determinado mês, portanto, resulta da soma de todos os créditos realizados no decorrer daquele mês. A periodicidade dos créditos varia, em função da origem dos recursos que compõem o Fundo, conforme demonstra o quadro abaixo:

\section{QUADRO 1}

\begin{tabular}{c|c}
\hline \multicolumn{2}{c}{ RECURSOS QUE COMPÕEM O FUNDEB } \\
\hline Origem & Periodicidade do crédito \\
\hline ICMS & Semanal \\
\hline $\begin{array}{c}\text { FPE, FPM, IPIexp e ITRm } \\
\text { Complementação da União } \\
\text { IPVA e ITCMD }\end{array}$ & Decendial \\
\hline \multicolumn{2}{c}{ Mensal } \\
\hline
\end{tabular}

Fonte: Manual de Orientação do Fundeb - 2008.

Conforme a lei 11.494/2007, que regulamenta o Fundeb, sua vigência é de 14 anos, a partir de $1^{\circ}$ de janeiro de 2007 e os percentuais de contribuição dos estados, do Distrito Federal e dos municípios para o Fundo sobre as receitas de impostos e transferências estão se elevando gradualmente até alcançar a plenitude em 2009, quando o Fundo estará funcionando plenamente, com todo o universo de alunos da educação básica pública presencial e os percentuais de receitas que o compõem terão alcançado o patamar de $20 \%$ de contribuição.

Pode-se destacar como avanço significativo trazido pelo Fundeb para a Educação básica a continuidade na valorização do profissional do magistério, por meio da lei de regulamentação, que prevê que os estados, o Distrito Federal e os municípios implantem seus Planos de Carreira e remuneração dos profissionais da educação básica, de modo a assegurar uma remuneração condigna para esses profissionais e a melhoria da qualidade do ensino e da 
aprendizagem e, ainda, a vinculação do percentual mínimo $60 \%$ dos recursos recebidos no âmbito do Fundo pelos estados, DF e municípios, para a remuneração desses profissionais, que estejam em pleno exercício de suas funções.

Para Symon Scwartzman (2005), no entanto, o desafio para elevar a qualidade da educação no Brasil está no comprometimento maior das pessoas envolvidas com a educação, que não são apenas os professores, mas também a família, os dirigentes e os alunos. Estes precisam aprender a gostar de estudar; os professores da rede pública precisam ter salários dignos, recursos pedagógicos adequados e programas de incentivo à educação continuada atrelados à remuneração por desempenho e competência; e as escolas precisam ter autonomia para a auto-gestão. Segundo o autor, esses fatores podem contribuir para que os profissionais de educação sintam-se co-responsáveis pelos resultados alcançados.

Outro avanço considerado significativo para o fortalecimento da democracia no país trazido pelo Fundeb para a Educação básica refere-se à maior transparência na gestão educacional, assegurada mediante a maior autonomia e proteção aos Conselhos de Acompanhamento e Controle Social do Fundeb. Esses conselhos são instrumentos de cidadania, de democracia e de controle do Estado. Envolvem o cidadão com os destinos da escola, ampliam os espaços públicos de decisão, têm a função de democratizar a informação para todos e podem controlar desmandos do poder. São uma promessa de participação que se vê realizada em experiências exitosas em vários municípios, concorrendo, dessa forma, para mais eficiência no gasto público, no planejamento e na gestão educacional e, conseqüentemente, para a melhoria da qualidade da educação no país.

Dessa forma, a lei de regulamentação do Fundeb, em seu artigo 24, determina a criação de Conselhos de Acompanhamento e Controle Social do Fundo nas três esferas de governo (federal, estadual e municipal), para que a sociedade participe de todo o processo de gestão dos recursos do Fundo, acompanhando as etapas relacionadas à previsão orçamentária, distribuição, aplicação e comprovação do emprego desses recursos.

Esses colegiados são formados por representações sociais variadas, e sua atuação deve acontecer com autonomia, sem subordinação e sem vinculação à administração pública estadual ou municipal. Com essas características, os Conselhos do Fundeb não são unidades administrativas do Governo local. Ao contrário, para que o acompanhamento seja efetivo, sua atuação deve ser pautada no interesse público, buscando o aprimoramento da relação formal e contínua com a Administração Pública local, responsável pela gestão e aplicação dos recursos do Fundo. 
Conforme o art. 24 da lei 11.494/2007, os conselhos do Fundeb devem ser criados por legislação específica, editada no pertinente âmbito governamental, com a representatividade, em âmbito federal, de no mínimo quatorze membros, sendo até quatro representantes do Ministério da Educação; um representante do Ministério da Fazenda; um representante do Ministério do Planejamento, Orçamento e Gestão; um representante do Conselho Nacional de Educação; um representante do Conselho Nacional de Secretários de Estado da Educação (CONSED); um representante da Confederação Nacional dos Trabalhadores em Educação (CNTE); um representante da União Nacional dos Dirigentes Municipais de Educação (UNDIME); dois representantes dos pais de alunos da educação básica pública; dois representantes dos estudantes da educação básica pública, um dos quais indicado pela União Brasileira de Estudantes Secundaristas (UBES).

Nos estados, os conselhos devem ser compostos por pelo menos doze membros, sendo: três representantes do Poder Executivo estadual, dos quais pelo menos um órgão estadual responsável pela educação básica; dois representantes dos Poderes Executivos Municipais; um representante do Conselho Estadual de Educação; um representante da seccional da UNDIME; um representante da seccional da CNTE; dois representantes dos pais de alunos da educação básica pública; dois representantes dos estudantes da educação básica pública, um dos quais indicado pela entidade estadual de estudantes secundaristas.

No Distrito Federal, o Conselho deve ser composto por, pelo menos, nove membros, com a mesma composição dos estados, excluídos os membros representantes dos Poderes Executivos Municipais e o representante da seccional da UNDIME.

Já nos municípios, os Conselhos do Fundeb devem contar com pelo menos nove membros, sendo dois representantes do Poder Executivo Municipal, dos quais pelo menos um da Secretaria Municipal de Educação; um representante dos professores da educação básica pública; um representante dos diretores das escolas básicas públicas; um representante dos servidores técnico-administrativos das escolas básicas públicas; dois representantes dos pais de alunos da educação básica pública; dois representantes dos estudantes da educação básica pública, um dos quais indicado pela entidade de estudantes secundaristas.

Ainda, devem compor o Conselho do Fundeb no âmbito municipal, um representante do Conselho Municipal de Educação e um do Conselho Tutelar, caso existam esses colegiados no município. Além do mínimo exigido para cada esfera de governo, outras representações poderão ter assento no Conselho do Fundeb, desde que na Lei de criação desse colegiado estejam previstas outras representatividades. 
Conforme a lei 11.494/2007, esses conselhos têm como atribuições acompanhar a distribuição, transferência e aplicação dos recursos do Fundeb; instruir, com parecer, a prestação de contas dos recursos do Fundo a ser encaminhada ao respectivo Tribunal de Contas; supervisionar o censo escolar e a elaboração da proposta orçamentária anual; e acompanhar a aplicação dos recursos transferidos à conta do Programa Nacional de Apoio ao Transporte do Escolar (PNATE).

Para reforçar a atuação autônoma dos conselhos do Fundeb, a lei 11.494/2007 determina que o presidente desse colegiado não seja representante do Poder Executivo e, ainda, define quais são os atores impedidos de compor o Conselho: i) cônjuge e parentes consangüíneos ou afins até o $3^{\circ}$ grau ou por adoção do prefeito, vice-prefeito e dos secretários municipais; ii) tesoureiro, contador ou funcionário de empresa de assessoria ou consultoria que prestem serviços relacionados à administração ou controle interno do Fundeb e seus parentes até o $3^{\circ}$ grau; estudantes não emancipados; e iii) pais de alunos que exercem cargos ou funções públicas de livre nomeação e exoneração ou que prestem serviços terceirizados ao Poder Executivo.

A lei que regulamenta o Fundeb ainda disciplina que esses conselhos não devem ser subordinados ou vinculados ao Poder Executivo ou a outros conselhos e para o seu bom funcionamento, o Poder Executivo deve assegurar infra-estrutura e condições materiais adequadas à execução plena das atividades do colegiado.

No entanto, ainda que o Fundeb represente uma dimensão peculiar do sistema federativo, não se podem analisar as políticas educacionais sem dimensionar a presença dos estados e municípios no processo educacional. São eles que levam adiante a implementação dessas políticas, especialmente no disciplinamento financeiro. Dessa forma, várias facetas da educação básica são levadas adiante pelos entes federados. E, dado nosso sistema político, a face de uma descentralização é imprescindível de ser considerada para uma análise objetiva da qualidade da educação. É preciso, pois, fazer estudos de caso como esse, para comparar situações e dimensionar, na concretização de uma política educacional, os limites, as redefinições e as possibilidades que o regime federativo introduz. Tedesco (2005) afirma que a maior autonomia das instituições educacionais e o maior controle dos resultados dessas instituições, acompanhados de mecanismos de compensação que garantam a eqüidade, parecem constituir o fundamento de transformações promissoras no âmbito educacional. 


\section{MÉTODOS E TÉCNICAS DE PESQUISA}

Esta pesquisa, de caráter qualitativo, direcionada ao estudo do funcionamento dos Conselhos de Acompanhamento e Controle Social do Fundeb no Maranhão e Piauí, considerou aspectos que influenciam na forma de atuação desses conselhos para o desempenho de suas funções, como os procedimentos para sua criação, a infra-estrutura disponibilizada ao Conselho pelo Poder Executivo para a operacionalização de suas atribuições, os problemas enfrentados para sua atuação, a interferência do Poder Executivo em suas decisões e, ainda, a conscientização dos conselheiros sobre o seu papel e o do Conselho na gestão da coisa pública.

O tema da democracia vinculado ao exercício da participação cidadã estimulou o interesse em estudar como os Conselhos de Acompanhamento e Controle Social do Fundeb nos estados do Maranhão e Piauí exercem o controle social sobre os recursos da educação básica pública, por se tratar de estados de onde são provenientes muitas reclamações da sociedade relacionadas à má aplicação de recursos públicos (conforme registros do FNDE) e onde se constata que grande parte dos conselhos não são atuantes. Diante desse panorama, portanto, julgou-se necessário investigar se esses conselhos estão assumindo suas funções conforme previsto em seu regulamento e de acordo com o compromisso com a res publica.

Utilizou-se como método de investigação a análise de conteúdo e o estudo de caso, combinado à análise documental, além de técnicas de pesquisa como entrevistas semiestruturadas, aplicação de questionários e grupo focal. Foram entrevistados dois conselheiros municipais do Fundeb no Piauí: um de Piripiri e outro de Teresina. Outros cento e treze conselheiros de diversos municípios do Maranhão e Piauí responderam o questionário sobre o funcionamento dos conselhos em seus municípios. Esse total de cento e quinze conselheiros participantes da pesquisa representa diversos segmentos, como dos professores, diretores, alunos, pais de alunos, funcionários técnico-administrativos das escolas, Conselho Municipal de Educação, Conselho Tutelar e Poder Executivo Municipal. Desse universo pesquisado, quarenta e sete conselheiros são de municípios do Maranhão e sessenta e oito do Piauí.

\subsection{Definições metodológicas}

A pesquisa, quanto ao seu fim, com base na tipologia adotada por Vergara (2004), pode ser classificada como exploratória, visto que buscou proporcionar maior familiaridade da pesquisadora com o objeto em estudo o qual se reporta ao funcionamento dos conselhos do 
Fundeb nos estados do Maranhão e Piauí, permitindo o acesso a dados esclarecedores para a compreensão e análise do universo da pesquisa. A pesquisa exploratória permite o tratamento de aspectos descritivos e explicativos, para melhor fundamentar a exploração dos casos levados em consideração neste estudo.

Quanto aos delineamentos da pesquisa, o trabalho adotou como estratégia metodológica o estudo de caso segundo Yin (2003), considerando que não havia estudo específico sobre o controle social do Fundeb nos estados do Maranhão e Piauí. Dessa forma, esse procedimento metodológico possibilitou uma pesquisa mais profunda das características específicas da cultura política nesses dois estados no acompanhamento da aplicação dos recursos públicos na educação básica pública. Neste sentido, utilizou-se a pesquisa qualitativa, como forma de abordagem do problema, que é a investigação de como os Conselhos do Fundeb exercem o controle social sobre os recursos da educação básica nos estados do Maranhão e Piauí, posto que se busca entender o fenômeno do controle social de forma mais detalhada, passando pela participação qualitativa dos pesquisados nos conselhos, por meio de descrições, comparações e abordagens interpretativas do objeto de estudo.

\subsection{Contexto da pesquisa}

A pesquisa foi desenvolvida nos estados do Maranhão e Piauí e foram convidados a participar da mesma todos os conselheiros do Fundeb que estiveram presentes nos Encontros Intermunicipais de Agentes de Controle Social dos Programas do FNDE dos respectivos estados, realizados nos meses de abril e maio de 2008, respectivamente.

Esses estados possuem a quantidade de municípios especificada no quadro abaixo, que estão representados na presente pesquisa por sessenta e oito conselheiros do Piaú e quarenta e sete do Maranhão:

QUADRO 2

\begin{tabular}{c|c|c|c|c}
\hline \multicolumn{5}{c}{ UNIVERSO DA PESQUISA } \\
\hline Estados & $\begin{array}{c}\text { Municípios } \\
\text { pesquisados }\end{array}$ & $\begin{array}{c}\text { Municípios com } \\
\text { Conselho do } \\
\text { Fundeb* }\end{array}$ & $\begin{array}{c}\text { Municípios } \\
\text { envolvidos na } \\
\text { pesquisa }\end{array}$ & $\begin{array}{c}\text { Conselheiros } \\
\text { envolvidos na } \\
\text { pesquisa }\end{array}$ \\
\hline Maranhão & 216 & 193 & 33 & 47 \\
\hline Piauí & 223 & 198 & $44^{* *}$ & 68 \\
\hline Total & & & $\mathbf{7 7}$ & $\mathbf{1 1 5}$ \\
\hline
\end{tabular}

Fonte: elaboração da autora.

*Conforme posição de 26/09/2008, do cadastro dos conselhos do Fundeb, mantido pelo FNDE

** Um município não identificado 


\subsection{Procedimentos de coleta de dados}

A pesquisa adotou como instrumentos de coleta de dados os seguintes recursos: a) entrevista semi-estruturada; b) grupo focal; c) questionário; d) análise documental. Os questionários foram entregues pessoalmente a cada um dos conselheiros do Fundeb participantes da pesquisa, com a informação de que os dados coletados são sigilosos e tratados de forma agregada, sem a identificação do respondente. Da mesma forma, foram realizados os grupos focais com a participação de seis voluntários no estado Piauí e sete no Maranhão. As entrevistas, que foram realizadas por meio eletrônico, em função do custo mais baixo e do tempo para desenvolvimento do trabalho, foram direcionadas a seis conselheiros municipais indicados pelos participantes dos grupos focais, todavia, apenas dois conselheiros responderam essa entrevista. Já a documentação do Conselho, solicitada aos treze conselheiros que participaram dos grupos focais, foi enviada por sete conselhos: três do Maranhão e quatro do Piauí.

\subsection{Análise e tratamento dos dados}

A análise dos dados foi realizada de forma qualitativa (de conteúdo) e quantitativa (estatística descritiva). A análise de conteúdo foi a ferramenta utilizada para interpretação das respostas aos questionários, aos grupos focais, às duas entrevistas e à documentação dos conselhos, buscando evitar entendimento superficial, reduzir a subjetividade e a utilização da intuição no processo interpretativo. Portanto, a análise dos dados qualitativos, obtidos por meio desses instrumentos de pesquisa, foi feita por meio de leitura crítica. Por se tratar de uma pesquisa aberta, por meio da qual os conselheiros manifestaram espontaneamente suas opiniões, conforme solicitado no enunciado de cada questão, as respostas foram consolidadas por grupos, considerando-se primeiramente os dados sociológicos dos conselheiros, a história e o funcionamento dos conselhos, os problemas para sua atuação para o controle social e a visão social do conselheiro sobre o papel do Conselho na gestão do Fundeb. Essa análise identificou pontos que merecem maior atenção e que devem ser mais valorizados pelo FNDE, como subsídio para realização de capacitação e apoio aos conselhos, para que essas instâncias representativas da sociedade civil possam ser mais bem preparadas para efetuar um acompanhamento efetivo da aplicação de recursos do Fundeb nas escolas públicas.

Os dados quantitativos, obtidos a partir da tabulação dos questionários, foram divididos e analisados também em grupos, considerando-se, da mesma forma que os dados 
qualitativos, os dados sociológicos dos conselheiros, a história e o funcionamento dos conselhos, os problemas para sua atuação e a visão social do conselheiro sobre a atuação do Conselho na gestão do Fundeb. Algumas perguntas, que provocaram respostas mais objetivas, foram transformadas em percentuais, para melhor interpretação dos dados coletados.

As informações foram analisadas por meio de gráficos e quadros, de forma a facilitar a compreensão e a relação entre as variáveis levantadas. 


\section{ESTUDO DE CASO: os conselhos do Fundeb no Maranhão e no Piauí}

Esse tópico apresenta a pesquisa de campo realizada nos estados do Maranhão e Piauí. Como será demonstrado, o acompanhamento da aplicação dos recursos do Fundeb, na maioria dos municípios pesquisados, se dá de forma deficitária. O estudo leva à reflexão sobre o verdadeiro papel que os conselhos do Fundeb estão desempenhando nos municípios pesquisados, que podem representar um avanço da democratização nesses municípios ou são apenas mais um mecanismo de legitimação dos gestores públicos, que criam uma suposta representatividade da sociedade e, conseqüentemente, um suposto controle social sobre as ações governamentais, ocasionando, dessa forma, prejuízo nos mecanismos de controle social e legitimação da democracia.

\subsection{Os conselhos do Fundeb no Maranhão}

Os conselhos do Fundeb do Maranhão que participaram da pesquisa são os dos municípios de: Afonso Cunha, Alcântara, Anapurus, Apicum-Açu, Axixá, Bacuri, Bacurituba, Barreirinhas, Brejo, Cachoeira Grande, Cajari, Cedral, Chapadinha, Cururupu, Governador Newton, Guimarães, Humberto de Campos, Icatu, Jenepapo dos Vieiras, Lago da Pedra, Lago do Junco, Lago dos Rodrigues, Lima Campos, Maranhãozinho, Matinha, Mirinzal, Olinda Nova, Porto Rico do Maranhão, Presidente Sarney, Santa Helena, Santa Inês, Serrano e Urbano Santos.

Segundo informações dos conselheiros dos municípios acima citados, depreende-se que os conselhos do Fundeb nesse estado, com poucas exceções, atuam de forma deficitária, visto que muitos conselheiros não têm a consciência cidadã de prestar um serviço de qualidade para o bem público e não têm o preparo devido para desempenhar bem a sua função. Além disso, em muitos casos não há apoio necessário do Poder Executivo Municipal para atuação do Conselho, impossibilitando que o trabalho do colegiado seja realizado a contento por não fornecer, por exemplo, o material de apoio necessário, o local próprio para as reuniões do colegiado e, muitas vezes, por não repassar sequer as prestações de contas a serem analisadas pelos conselhos.

Por esse motivo, muitos dos conselheiros do Maranhão que fizeram parte da pesquisa se mostraram desestimulados e decepcionados com o poder público, posto que, mesmo com o direcionamento de considerável valor de recursos públicos para a educação, ainda existem escolas públicas funcionando de forma precária e há, ainda, casos de desvio dos recursos do 
Fundeb para finalidades não previstas nos regulamentos que regem a aplicação dos recursos do Fundo na educação pública.

\subsection{Os conselhos do Fundeb no Piauí}

Os conselhos do Fundeb no Piauí que participaram da pesquisa são os dos municípios de: Alto Longa, Amarante, Barras, Barro Duro, Beneditinos, Boa-Hora, Bom Principio, Boqueirão, Brasileira, Buriti dos Lopes, Buriti dos Montes, Cabeceiras do Piauí, CampoMaior, Capitão de Campos, Caraúbas, Castelo do Piauí, Cocal dos Alves, Coivaras, Demerval Lobão, Ilha Grande, Joaquim Pires, Joca Marques, José de Freitas, Lagoa Alegre, Matias Olímpio, Miguel Alves, Milton Brandão, Monsenhor Gil, Monsenhor Hipólito, Morro do Chapéu, Nossa Senhora dos Remédios, Parnaíba, Pedro II, Piripiri, Porto, Regeneração, Santana do Piauí, São João do Arraial, São Miguel do Tapuio, São Pedro, Sigefredo Pacheco, Teresina e União.

A pesquisa demonstra que esses conselhos, de um modo geral, são mais atuantes que os conselhos pesquisados do Maranhão, no entanto, há algumas situações bastante contraditórias. Enquanto alguns conselheiros julgam que seus conselhos têm uma boa atuação na co-gestão da aplicação dos recursos da educação, outros declararam que seus conselhos atuam de maneira precária, sem muito envolvimento de seus membros, que vão às reuniões apenas para assinar os documentos de prestação de contas, sem análise prévia. O levantamento realizado durante a pesquisa revela que, em geral, não há um desempenho dos membros dos conselhos nos municípios que possa levar os conselhos a exercerem, por intermédio de suas atuações, um papel democratizador e efetivamente fiscalizador, remetendo aos pressupostos do controle social.

O Conselho Municipal do Fundeb em Teresina - Piauí (formado por meio de Câmara específica), no entanto, chamou a atenção por demonstrar que seu funcionamento se dá com total autonomia, realizando trabalho minucioso na análise das prestações de contas relacionadas ao Fundeb, além de visitar as escolas para acompanhar seu funcionamento, inspecionar as obras de edificação e reforma de escolas, divulgar suas ações à população e realizar cursos de capacitação para outros conselhos, sobre a lei que regulamenta o Fundo. Esse Conselho é um bom exemplo de controle social, visto que funciona como espaço público democrático atuante, no qual todos os seus componentes são respeitados e se interessam em realizar o melhor em benefício do bem comum, desempenhando suas funções com responsabilidade e atuando efetivamente na co-gestão da coisa pública, em total harmonia 
com o Poder Público local, porém, com autonomia e soberania em suas decisões. As investigações a respeito do Conselho evidencia que o caráter individual de satisfação das necessidades sociais leva a uma preocupação que é central no debate da cidadania, como já defendiam Arendt (2006) e Mouffe (1996). O Conselho do município de Teresina, por meio das entrevistas, demonstrou que há um sentimento de pertencimento, de identidade, no qual os seus componentes se reconhecem e se sentem integrados. Assim como idealizado por Mouffe (1996), o Conselho de Teresina aceitou a necessidade do político e a impossibilidade de um mundo sem antagonismos, mantendo uma ordem democrática pluralista nessas condições.

\subsection{Os conselhos como espaços públicos}

A idéia segundo a qual o cidadão tem o dever de participar mais incisivamente na gestão da coisa pública remonta à Grécia Antiga. Contemporaneamente, a participação cidadã nos negócios de interesse público, nas decisões governamentais passaram a ser evocados com mais robustez na década de 1960, com os movimentos estudantis e comunitários surgidos nos países democráticos europeus. O desafio naquela época consistia fundamentalmente na garantia de mecanismos concedidos pelo Estado de participação do cidadão na vida pública como direito. Esse desafio era ainda mais urgente nos países de pouco ou frágil existência democrática no contexto político dos países latino-americanos das décadas entre 1960 e 80. No caso do Brasil, pode-se dizer, que a problemática gira em torno de como motivar os cidadãos para que se envolvam politicamente nos assuntos de interesse coletivo, apesar da Constituição de 1988 está assentada nos princípios de descentralização da administração

pública e no controle social. À primeira vista, pode-se arriscar dizer que se trata de um reforço à manifestação de esferas públicas como espaços coletivos de defesa de interesses comuns.

Nessa linha de raciocínio, Pateman (1992) entende que a participação mais ampla na esfera pública começa necessariamente com a participação em micro-esferas da vida social, como os espaços públicos, posto que "as pessoas com senso de eficácia política têm mais probabilidade de participar da política do que aquelas que carecem desse sentimento" (PATEMAN, 1992, p. 66).

Os conselhos, portanto, devem ser espaços públicos onde acontecem encontros de articulação entre os agentes políticos e sociais, condição fundamental para o resgate da legitimidade do Estado, que deve aperfeiçoar seus instrumentos de governabilidade e criar novas estruturas de governança, estimulando a participação da sociedade para uma democracia participativa e associativa (DAGNINO, 2002). 
Nessa linha de pensamento, entende-se que a participação de entidades da sociedade civil na gestão pública oxigena os governos locais e lhes dá mais transparência, além de aproximá-los mais da população e de lhes disponibilizar oportunidade de realizar redirecionamento e correção de suas políticas. Por essa razão, a participação da sociedade civil de forma engajada e paritária nos conselhos do Fundeb é de fundamental importância para que esse espaço público seja de fato um canal aberto entre a população e o governo, trazendo maior publicização e transparência à implementação das políticas educacionais locais.

$\mathrm{Na}$ pesquisa realizada, verifica-se que os conselhos nem sempre funcionam como esses espaços públicos definidos por Dagnino e menos ainda nos termos concebidos por Arendt (2006; 2007) que se refere ao exercício da política na esfera pública como locus que assume seus atributos mais autênticos e autônomos quando prevalece sua dimensão política. Nessa mesma linha de entendimento, Habermas (2002) defende que a sociedade terá resultados diferentes, tanto na concepção republicana do Estado como uma comunidade ética, quanto em relação à concepção liberal do Estado como defensor de uma sociedade econômica, quando o conceito procedimental da política deliberativa se torna o centro consistente da teoria sobre a democracia, entendimento nem sempre vislumbrado pelos municípios.

No que concerne a espaços públicos formais, ou seja, institucionalizados, foi revelado que $84,4 \%$ dos conselhos pesquisados foram formalmente criados por meio de Ato legal. Os 15,6\% restantes somam onze conselhos que não responderam a pesquisa e um que ainda não foi criado, em descumprimento à determinação legal de regulamentação do Fundeb. Outro fator curioso é que a quase totalidade dos conselhos pesquisados (96\%) optou por mandato de dois anos, limite máximo estipulado na lei de regulamentação do Fundo, para incentivar o revezamento e evitar a perpetuação das mesmas pessoas no colegiado. Embora a pesquisa aponte um alto percentual de conselhos com período de mandato já definido para dois anos, 10,6\% dos conselhos ainda não elaboraram seu Regimento Interno, para disciplinar a execução de suas atividades, significando, com isso, que esses conselhos não estão em pleno funcionamento de suas atividades. Quanto à composição desses conselhos, em 29,9\% deles não há composição mínima compatível com a representatividade devida para o bom desempenho do colegiado como espaço público, onde deve haver paridade entre os segmentos representados e onde todos esses segmentos devem ter a mesma importância no debate político, como espaço democrático, para que haja o exercício da democracia plena. O Quadro 3 demonstra essa e outras situações relevantes. 
QUADRO 3

\begin{tabular}{|c|c|c|c|c|c|}
\hline \multicolumn{6}{|c|}{ HISTÓRIA DOS CONSELHOS } \\
\hline & & \multicolumn{3}{|c|}{ Composição } & \multirow{2}{*}{$\begin{array}{l}\text { Conselhos com membros não } \\
\text { indicados pelo segmento que } \\
\text { representam (indicados pelo } \\
\text { Poder Executivo) }\end{array}$} \\
\hline & & $\begin{array}{c}\text { Com } 9 \text { ou mais } \\
\text { membros }\end{array}$ & $\begin{array}{c}\text { Abaixo de } 9 \\
\text { membros }\end{array}$ & Não respondeu & \\
\hline \multirow{2}{*}{ MA } & Quantidade & 21 & 11 & 1 & 2 \\
\hline & $\%$ & 63,6 & 33,4 & 3 & 6,1 \\
\hline \multirow{2}{*}{ PI } & Quantidade & 30 & 12 & 2 & 5 \\
\hline & $\%$ & 68,2 & 27,3 & 4,5 & 11,4 \\
\hline
\end{tabular}

Fonte: elaboração da autora.

Essa realidade apresentada no Quadro 3 compromete o exercício da democracia na gestão da coisa pública nos municípios pesquisados, posto que $33,4 \%$ dos conselhos no Maranhão e 27,3\% no Piauí não possuem a representatividade mínima exigida pela legislação. Outro relevante problema levantado na pesquisa e demonstrado também no Quadro 3 é o fato de que, embora muitos conselhos tenham composição condizente com a legislação que regulamenta o Fundeb, ou seja, mesmo com uma significante participação da sociedade civil, um número expressivo de seus membros são erroneamente indicados pelo Poder Executivo local, ao invés de serem indicados pelos segmentos que eles representam, comprovando a interferência do governo nos espaços públicos onde deveriam prevalecer o interesse da comunidade. Essa realidade evidencia que em alguns municípios, embora haja o Conselho do Fundeb legalmente constituído, não há o exercício de controle sobre os recursos públicos da educação pela sociedade civil e sim pelo Poder Executivo, que interfere na representatividade da composição do Conselho e mascara uma situação totalmente irregular. Nesses casos, o que se vê são conselhos que, embora se constituam em espaço de participação da sociedade na gestão da coisa pública, se transformam em um apêndice do Poder Executivo local.

Além disso, foi constatado na pesquisa que de todos os conselhos pesquisados, apenas quatro abriram espaço para representatividade de segmentos adicionais aos determinados pela legislação do Fundo, significando que na maioria dos municípios 
não foram ampliados assentos para demais membros da sociedade civil nesse espaço público.

Outro ponto preocupante é o fato de $23,8 \%$ dos conselhos pesquisados terem declarado que suas reuniões são realizadas bimestral, trimestral ou semestralmente, como mostra o gráfico 1.

\section{Gráfico 1: Periodicidade das reuniões}

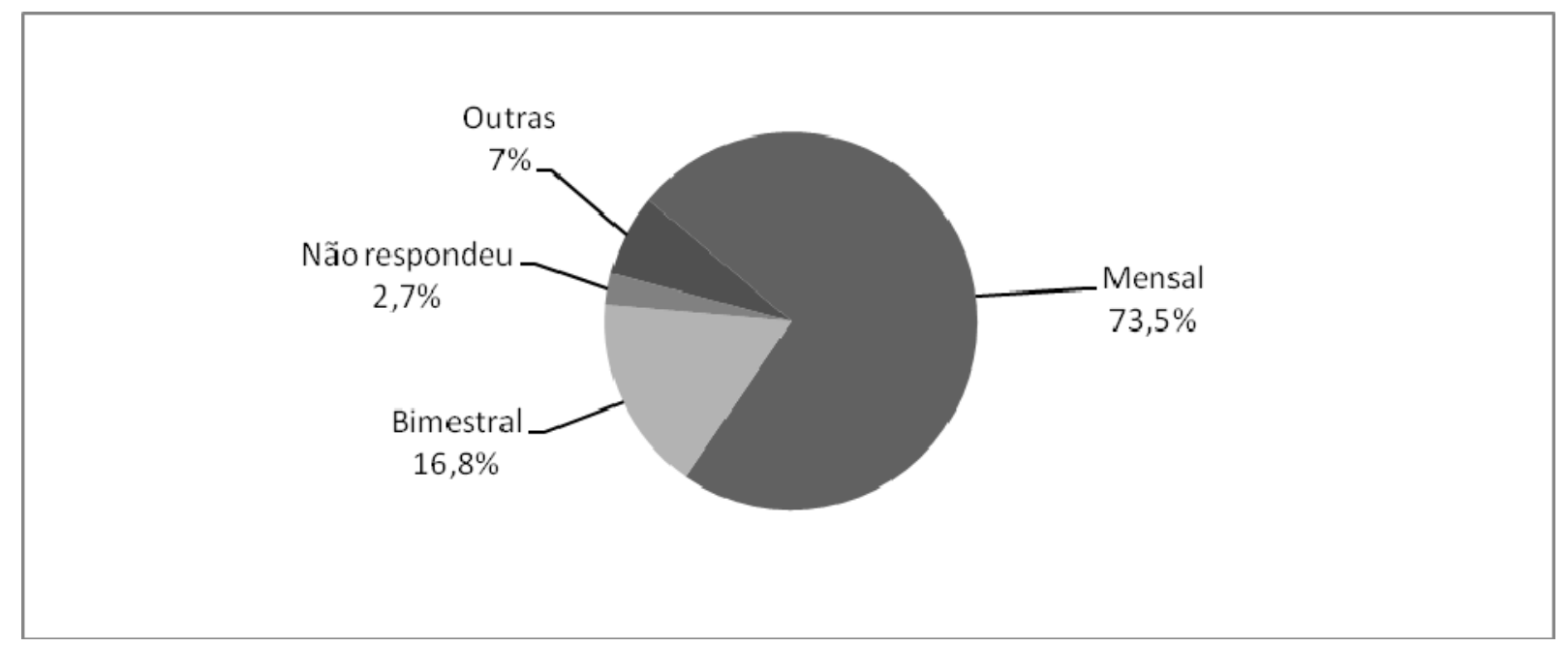

Fonte: elaboração da autora.

Sendo a periodicidade das reuniões um fator muito importante para o bom acompanhamento da aplicação dos recursos do Fundeb, as reuniões em todos os conselhos deveriam ser realizadas pelo menos com a periodicidade mensal, já que os governos municipais devem apresentar mensalmente aos conselhos os demonstrativos da utilização dos recursos do Fundeb. Dessa forma, a periodicidade mensal contribuiria para a atuação dos conselheiros como sujeitos políticos atuantes, capazes de orientar e fiscalizar de perto a ação do governo local no que tange aos assuntos educacionais.

A pesquisa revelou, ainda, que a maioria dos membros interessados em participar de capacitações para Conselhos do Fundeb e/ou que são indicados pelos gestores municipais para as referidas capacitações são, em sua maioria, professores da educação básica da rede pública com nível de escolaridade de ensino superior e alguns até com pós-graduação, evidenciando, dessa forma, que os conselheiros com menor grau de instrução têm menos oportunidade para serem capacitados ou menos interesse em desempenhar seu papel de cidadão em espaços públicos, pelo menos nos casos estudados. O Quadro abaixo demonstra essa situação, dentre outras. 
QUADRO 4

\begin{tabular}{|c|c|c|c|c|c|}
\hline \multicolumn{6}{|c|}{ PERFIL SOCIOLÓGICO DOS CONSELHEIROS PARTICIPANTES DA PESQUISA } \\
\hline & & \multicolumn{2}{|c|}{ MA } & \multicolumn{2}{|c|}{ PI } \\
\hline & & QUANT. & $\%$ & QUANT. & $\%$ \\
\hline \multirow{3}{*}{ Idade } & Abaixo de 40 anos & 27 & 57,5 & 38 & 57,6 \\
\hline & Acima de 40 anos & 19 & 40,4 & 24 & 36,3 \\
\hline & Não respondeu & 1 & 2,1 & 4 & 6,1 \\
\hline \multirow{3}{*}{ Profissão } & Professor & 37 & 78,7 & 54 & 81,8 \\
\hline & Outras & 9 & 19,2 & 12 & 25,5 \\
\hline & Não respondeu & 1 & 2,1 & - & - \\
\hline \multirow{5}{*}{ Escolaridade } & Pós-graduação & - & - & 7 & 10,6 \\
\hline & Superior (cursando ou completo) & 35 & 74,5 & 51 & 77,3 \\
\hline & Médio (cursando ou completo) & 9 & 19,2 & 8 & 12,1 \\
\hline & $\begin{array}{l}\text { Fundamental (cursando ou } \\
\text { completo) }\end{array}$ & 2 & 4,2 & - & - \\
\hline & Não respondeu & 1 & 2,1 & - & - \\
\hline \multirow{6}{*}{$\begin{array}{l}\text { Segmento que } \\
\text { representa }\end{array}$} & Professor & 18 & 38,3 & 10 & 15,1 \\
\hline & Diretor & 10 & 21,3 & 10 & 15,1 \\
\hline & $\begin{array}{l}\text { Pais de alunos, Alunos e } \\
\text { comunidade }\end{array}$ & 6 & 12,8 & 3 & 4,6 \\
\hline & Secretaria Municipal de Educação & 5 & 10,6 & 10 & 15,1 \\
\hline & Outros & 7 & 14,9 & 9 & 13,7 \\
\hline & Não respondeu & 1 & 2,1 & 24 & 36,4 \\
\hline
\end{tabular}

Fonte: elaboração da autora.

É relevante o fato de que, conforme mostra o Quadro 4, dentre os atores que se apresentaram como voluntários para a realização da pesquisa, foram identificados 41 conselheiros e 72 conselheiras, confirmando que a educação básica, que historicamente sempre foi mais assumida pelo sexo feminino, está ampliando espaço para a representatividade masculina, evidenciando que os homens têm aumentado interesse pelo acompanhamento e desenvolvimento da educação infantil e dos ensinos fundamental e médio. 
Além desse fator, o Quadro 4 apresenta alguns pontos considerados também relevantes, como a idade dos conselheiros, que na sua maioria possui menos de 40 anos, demonstrando que a conscientização do dever cívico tem se fortalecido cada vez mais na população mais jovem.

O Quadro 4 também demonstra um fato intrigante que se refere à profissão dos conselheiros, apresentando um percentual muito elevado de professores e indicando, dessa forma, que os cidadãos que mais se interessam em acompanhar os recursos do Fundeb são aqueles envolvidos diretamente pelo aspecto salarial, pois na definição de aplicação dos recursos do Fundeb, a legislação determina que o mínimo de $60 \%$ dos recursos do Fundo sejam aplicados justamente no pagamento dos salários dos professores. Essa alta representatividade de professores no Conselho do Fundeb pode influenciar para uma priorização do bem privado em detrimento do comprometimento com o bem comum, já que há interesses particulares envolvidos no processo, que podem se sobressair sobre os interesses coletivos, sobretudo quando não é o interesse cívico que rege a motivação dos conselheiros.

Por outro lado, segundo a pesquisa, quase que a totalidade dos presidentes dos conselhos nos dois estados estudados representa segmentos da sociedade civil, permitidos pela legislação, exceto em quatro casos, três no Maranhão e um no Piauí, em que os presidentes são representantes do Poder Executivo Municipal, situação explicitamente proibida pelo parágrafo $5^{\circ}$ do art. 24 da lei 11.494/2007, para não descaracterizar o controle social, já que o Conselho existe exatamente para acompanhar os gastos do Poder Executivo com a educação. Da mesma forma, um alto percentual dos conselhos pesquisados tem seus presidentes eleitos por seus pares em reunião do colegiado, no entanto, em três casos no Maranhão e um no Piauí, os presidentes foram impostos pelo poder executivo local, situação também explicitamente impedida no mandamento legal, que gera o total desrespeito com os espaços públicos organizados.

Outro fato curioso que a pesquisa demonstrou é que 34\% dos presidentes dos conselhos do Fundeb pesquisados (26 conselhos) são representantes do segmento de professores e 34\% dos diretores, tendo-se, dessa forma, 68\% dos conselhos do Fundeb presididos por representantes desses dois segmentos. Nesse caso, o preocupante é que dos $34 \%$ dos presidentes representantes dos diretores, não se sabe quais deles verdadeiramente representam os interesses do segmento, já que na maioria dos municípios brasileiros o cargo de diretor, ao invés de ser escolhido por meio de eleição de seus pares, é uma função de confiança do Poder Executivo Municipal, fazendo com isso que, pelo viés de legislações locais, o objetivo do mandamento legal que regulamenta o Fundeb seja descumprido e o poder público continue no 
controle das decisões do Conselho, como o caso de um dos Conselhos pesquisados no Maranhão, que conforme relato de um de seus conselheiros, "o cargo de presidente foi tramado. O Secretário de Educação conversou com os alunos e um pai para votarem na diretora, em troca de alguns benefícios. A diretora é contratada: cargo comissionado”.

A realidade levantada nos municípios pesquisados revela, em geral, que não há um bom desempenho dos conselheiros do Fundeb nos municípios que possa levar os conselhos a exercerem, por intermédio de suas atuações, um papel democratizador e efetivamente fiscalizador. Conhecer a atuação dos conselhos do Fundeb nos municípios possibilitou levantar aspectos interessantes, como a forma como os conselhos são compostos, porém, o indicativo de que os conselhos devem ter elementos representativos da sociedade em sua composição, eleitos ou indicados por seus pares, não são garantia de que os conselhos sejam realmente a evidência do processo democrático. Conforme Oliveira (1999, p. 233):

... o esforço pela inclusão de determinados dispositivos na lei, pela sistematização de sua interpretação e a sua divulgação para amplas parcelas da população terá sido em vão se não se conseguir incorporar o que estas leis trazem de democrático e emancipador ao cotidiano das populações excluídas de direitos. Isto implica enfrentar uma questão crucial da educação política. Não basta uma legislação de defesa dos direitos do homem; temos que ter uma população disposta a defendê-la enquanto prática social concreta.

Nessa linha de raciocínio, conclui-se que não basta a criação de leis determinando a implementação dos conselhos para que haja o controle público, como forma de administrar o bem público. Para o controle público, é necessário, sim, ações de maior abrangência por implicar em processos culturais e políticos de transformação da organização social, que exigem alteração de postura dos cidadãos e profissionais que fazem parte do Conselho.

Por fim, confirmando o que apresenta a literatura estudada neste trabalho, a relação entre o público e o privado muito influencia para o sucesso da gestão da coisa pública e, pelo fato da participação popular encontrar na esfera pública ambiente favorável à ampliação da democracia em escala local, permitindo mais aproximação com os problemas da comunidade, onde no conflito de interesses deve prevalecer sempre é o bem comum, no entanto, não é o que acontece recorrentemente nos casos dos conselhos existentes nos municípios pesquisados.

\subsection{Os conselhos como mecanismos de controle social na gestão da educação básica pública}


A formatação dada aos conselhos de controle e acompanhamento, como é o caso dos conselhos do Fundeb, diz respeito, essencialmente ao lugar atribuído à democracia representativa na instituição democrática brasileira e, especificamente, ao papel conferido à sociedade civil na sua relação com o Poder Público.

A comunidade organizada exerce importantes meios de controle social capazes de oferecer maior transparência à gestão pública e que contribuem para uma melhor qualidade dos serviços oferecidos à comunidade. Os conselhos, sem dúvida, têm se tornado em um forte espaço de controle social, mesmo diante das dificuldades encontradas pela sociedade civil e pelos movimentos sociais para a ocupação de forma propositiva destes espaços e diante das dificuldades de mudanças culturais da gestão pública.

Os conselhos do Fundeb, como mecanismos de controle social na gestão da educação básica pública ainda deixam muito a desejar para que, de fato, exerçam controle social e participem com eficiência e eficácia da gestão do bem público. O funcionamento dos conselhos, conforme a pesquisa, indica que o trabalho desses colegiados se dá de forma precária em 17,2\% dos conselhos pesquisados no Maranhão e 24,2\% no Piauí, posto que o Poder Executivo local não disponibiliza a infra-estrutura necessária para realização das atividades desses colegiados. Essas carências vão desde a escassez de material de expediente até a falta de espaço físico específico para reuniões e de documentação necessária para realização do trabalho de acompanhamento da gestão dos recursos públicos destinados à educação. Além da falta de estrutura, o mais grave é a realidade de $9,7 \%$ dos conselheiros pesquisados não entenderem sequer qual é a sua função no Conselho, se restringindo apenas a informar, por exemplo, que seu papel é “participar das reuniões” ou “obedecer a compromisso”, como relatado pela conselheira Arilza Ramos (pseudônimo) ${ }^{7}$, quando foi perguntado como os conselheiros desempenham suas funções e quais as ações práticas desenvolvidas pelos conselheiros: "Na medida do possível, obedecendo sempre o compromisso... participando das reuniões... registrando tudo em ata”

Além disso, a pesquisa demonstra que 22,1\% dos conselhos não atuam como espaço democrático, sendo manipulados pelo gestor público local, que toma decisões, usa poder de convencimento e dificulta acesso a documentos, fazendo com que os conselhos se limitem apenas a assinar o que é definido por ele e, conseqüentemente, não disponham

7 Pseudônimo utilizado para preservar a identidade do entrevistado, nesse caso e em todos demais nomes dos conselheiros citados neste trabalho. 
de autonomia total para exercer sua função, conforme demonstra o Quadro 5. Como declarado pelos próprios conselheiros pesquisados, isso ocorre por falta de conhecimento do real significado de controle social, falta de interesse efetivo pelo bem público e falta de conscientização em relação ao verdadeiro significado de democracia.

\section{QUADRO 5}

\begin{tabular}{c|c|c|c|c}
\hline \multicolumn{5}{c}{ ATUAÇÃO DOS CONSELHOS } \\
\hline \multirow{2}{*}{} & $\begin{array}{c}\text { Conselhos } \\
\text { atuantes }\end{array}$ & $\begin{array}{c}\text { Conselhos com } \\
\text { autonomia considerada } \\
\text { boa ou ótima }\end{array}$ & $\begin{array}{c}\text { Conselhos com } \\
\text { legitimidade em suas } \\
\text { decisões }\end{array}$ \\
\hline \multirow{2}{*}{ MA } & Quantidade & 21 & 18 & 27 \\
\cline { 2 - 5 } & $\mathbf{\%}$ & $\mathbf{4 4 , 7}$ & $\mathbf{3 8 , 2}$ & $\mathbf{5 7 , 4}$ \\
\hline \multirow{2}{*}{ PI } & Quantidade & 35 & 34 & 40 \\
\cline { 2 - 6 } & $\mathbf{\%}$ & $\mathbf{5 3}$ & $\mathbf{5 1 , 5}$ & $\mathbf{6 0 , 6}$ \\
\hline
\end{tabular}

Fonte: elaboração da autora.

Em virtude desses fatores apresentados no Quadro 5, o percentual considerável de 6,5\% dos municípios consideram que suas decisões não adquirem legitimidade (6,5\% não responderam), não atuando, portanto, como real mecanismo de controle da gestão pública educacional. Diferentemente da maioria dos conselhos pesquisados, alguns conselhos declararam que se empenham para cumprir seu papel fiscalizador e controlador, acompanhando e analisando a aplicação dos recursos do Fundeb com autonomia e interesse, além de verificar in loco os trabalhos executados com essa parcela de recursos públicos da educação.

Por último, a pesquisa buscou informações sobre a avaliação de cada conselheiro sobre o papel do Conselho na gestão do Fundeb, especificando o seu interesse em participar do controle e acompanhamento da gestão pública e apontando a importância do Conselho do Fundeb nessa gestão. Nesses aspectos, 90,3\% dos conselheiros informaram que participam do Conselho do Fundeb para se manterem atualizados sobre os programas de governo e para divulgar informações sobre direitos sociais, além de acompanharem e fiscalizarem a gestão pública na área da educação e colaborarem com seu desempenho. 
Quanto ao entendimento do verdadeiro valor do controle social, 86,7\% dos conselheiros responderam que o Conselho do Fundeb tem grande importância na gestão e aplicação dos recursos públicos, para acompanhar e fiscalizar a aplicação dos recursos da educação e impedir desvios desses recursos, contribuindo com o desenvolvimento do município. Isso demonstra que a sociedade dos municípios pesquisados, a despeito de todas as dificuldades, está em direção de uma visão mais consciente do que pode ser realizado em prol dos interesses coletivos, demonstrando que deve haver engajamento para isso, como demonstra a resposta do conselheiro Francisco Franco (pseudônimo), do estado do Piauí, quando considera que os conselhos do Fundeb são espaços democráticos em que o cidadão pode exercer controle social sobre o Fundo, enfatizando que em seu município:

Qualquer cidadão pode assistir nossa reunião. Quando fazemos visitas ouvimos a todos que queiram dizer algo sobre a obra, da diretora ao vigia. Anotamos, fazemos relatório das visitas e encaminhamos ao gestor o resultado do averiguado. Solicitamos providências para solução dos problemas, cobramos resposta do solicitado e tem funcionado. Mas sempre tem a melhorar e essa será a nossa busca: fazer cada vez melhor .

No que tange à motivação para compor o Conselho, com base nas respostas dos conselheiros, é possível afirmar que 63,7\% dos respondentes (somando-se os municípios pesquisados dos dois estados) têm como motivação conhecer, acompanhar e fiscalizar as ações do poder público, referentes à educação e, ainda, contribuir para o desenvolvimento da educação, a despeito da minoria (30,1\%) que faz parte do Conselho apenas por indicação ou convite ou, ainda, com a visão de defender a sua categoria profissional. Conforme afirmação da conselheira Maria Hilda Pires (pseudônimo), em seu município há até dificuldade de se formar o Conselho, devido ao seguinte fator:

Ninguém quer participar... ninguém quer trabalhar de graça... o mais agravante e faz com que o Conselho não desempenhe o seu papel é a questão da falta de conscientização. Eles não sabem a responsabilidade, o poder que eles têm. Eles ainda têm a cultura de fazer o que o prefeito diz e afirmam que não vão entrar no Conselho para não desagradar. 
A pesquisa ainda constatou que a falta de motivação ou mesmo de interesse por parte de alguns membros do Conselho se dá em decorrência de que eles não querem se indispor com o Poder Executivo local e para tanto, se mantêm apáticos aos assuntos e ações do colegiado. O gráfico abaixo apresenta o grau de motivação dos conselheiros pesquisados em atuarem no Conselho do Fundeb.

\section{Gráfico 2: Motivação para compor o Conselho}

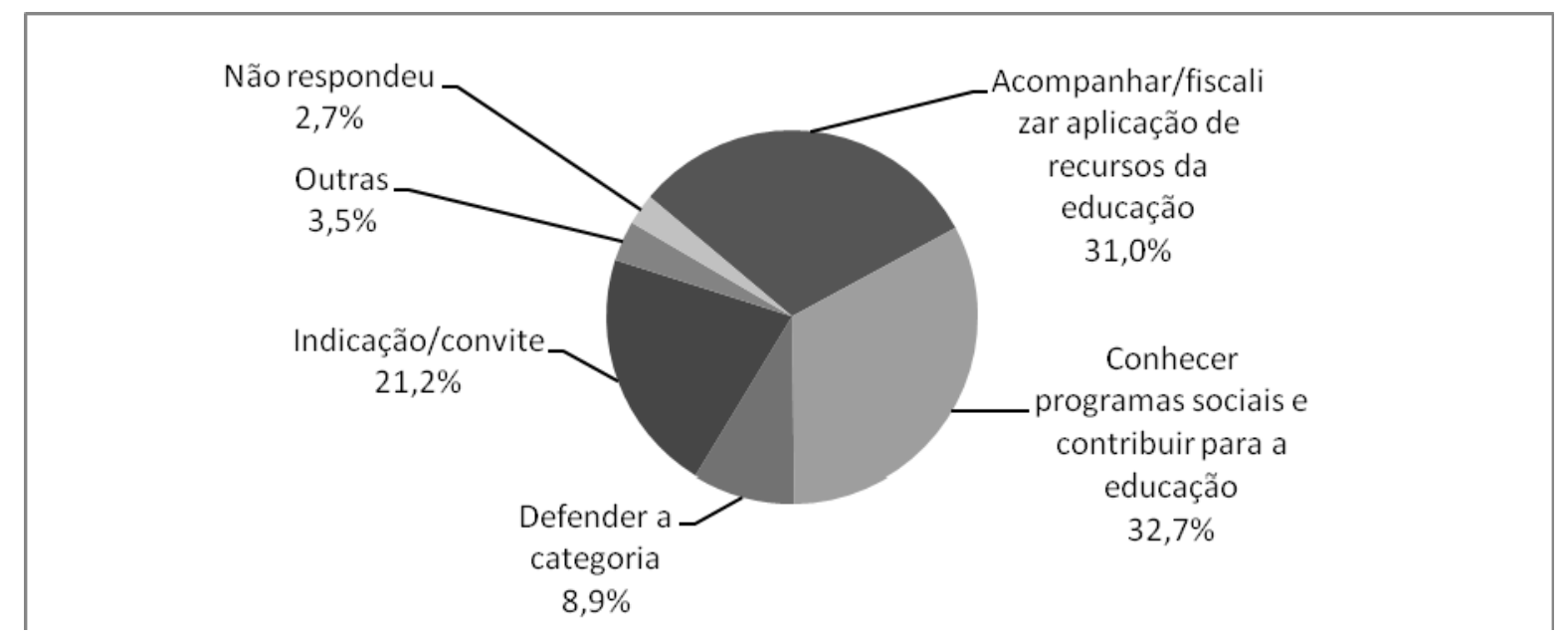

Fonte: elaboração da autora.

Como se pode constatar no Gráfico acima, 33,6\% dos conselheiros pesquisados têm motivações opostas daquelas idealizadas pelos estudiosos mencionados neste trabalho, inviabilizando o exercício do processo democrático e da cidadania em prol do bem comum, posto que as ações são mais praticadas em função dos interesses privados, em detrimento do bem da coletividade. Essa realidade evidencia que muitos conselheiros ainda não entendem o real sentido do controle social e não têm seque a noção do que esse termo significa, atuando no Conselho apenas por interesses particulares, como por exemplo, por terem parentes na escola ou para defender seus salários. O gráfico abaixo apresenta o percentual de conselheiros pesquisados que demonstram conhecer o real sentido do termo "controle social”.

\section{Gráfico 3: Entendimento sobre o significado de controle social}




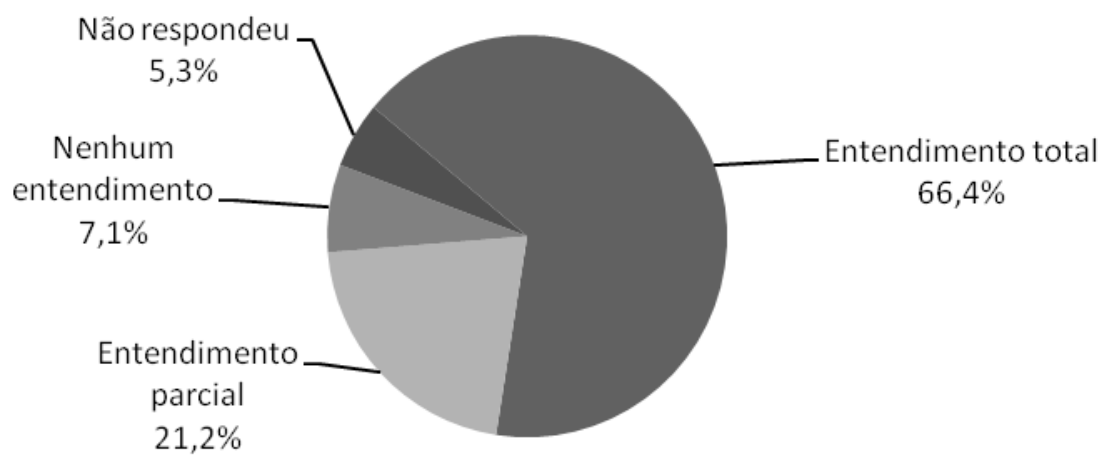

Fonte: elaboração da autora

Por reconhecer o retrato apresentado no Gráfico 3, a maioria dos conselheiros participantes da pesquisa demonstrou interesse em realizar cursos de capacitação para melhor exercerem seu papel de cidadãos na co-gestão da coisa pública. E, com a intenção de bem desempenharem suas atividades, 69\% deles declararam que não têm capacitação necessária para o desempenho de suas atribuições e 82,3\% sugeriram que o governo federal providencie equipes técnicas para realização de capacitações periódicas a todos os conselheiros, já que muitos não sabem sequer o seu papel, sendo esse um fator crucial para a boa gestão participativa, visto que as funções a serem desempenhadas por esses colegiados demandam conhecimentos específicos e, principalmente, a conscientização sobre cidadania e controle social. O quadro abaixo demonstra essa necessidade.

QUADRO 6

\begin{tabular}{|c|c|c|c|c|}
\hline \multicolumn{5}{|c|}{$\begin{array}{l}\text { ENTENDIMENTO DOS CONSELHEIROS SOBRE NECESSIDADE DE } \\
\text { CAPACITAÇÃO }\end{array}$} \\
\hline \multicolumn{4}{|c|}{ Entende que tem capacitação necessária } & \multirow{2}{*}{$\begin{array}{c}\text { Solicita capacitação } \\
\text { periódica }\end{array}$} \\
\hline & Sim & Não & Não respondeu & \\
\hline Quantidade & 26 & 78 & 9 & 93 \\
\hline$\%$ & $23 \%$ & $69 \%$ & $8 \%$ & $82,3 \%$ \\
\hline
\end{tabular}

Fonte: elaboração da autora.

Como demonstrado no Quadro acima, 93\% dos conselheiros pesquisados declaram a necessidade de capacitação para acompanhamento da aplicação de recursos do Fundeb. Na 
maioria dos casos, eles solicitam que o FNDE providencie a realização de cursos de capacitação para todos os conselheiros, já que os municípios não se dispõem a custear a capacitação dos mesmos, causando, dessa maneira, um desnivelamento na formação e na motivação entre os membros do colegiado, já que uns participam de capacitações e outros não. Como evidência desse fato, em uma das entrevistas, quando foi perguntado se os conselheiros que compõem o Conselho do Fundeb no município estão capacitados para desempenhar suas funções, obteve-se a seguinte resposta da conselheira Bernardina Silva (pseudônimo):

A maioria não está capacitada, alguns não sabem nem a função do conselho e dos que têm conhecimento uns são omissos. Por vivermos em uma cidade pequena e tudo girar em torno da política partidária, alguns representantes jamais ficarão contra as solicitações do executivo, por medo de serem prejudicados de alguma forma.

Analisando a necessidade de capacitação dos conselheiros do Fundeb com um foco diferente do acima mencionado, a conselheira Bernadete Azevedo (pseudônimo), durante o debate do Grupo Focal, afirmou que "uma maneira de evitar que os prefeitos desviem recursos públicos é capacitar os conselheiros, para que o Conselho se fortaleça no desempenho de suas atribuições”.

Demonstrando a mesma necessidade de capacitação, o conselheiro Manoel de Souza (pseudônimo) afirmou que em seu município "a maior dificuldade com o Conselho é a questão da capacitação, porque todos nós não temos a mesma capacitação, a maioria não tem o conhecimento que alguns têm nos cursos”.

Com essas afirmações, verifica-se a grande necessidade de capacitação dos conselheiros do Fundeb para melhor desempenharem suas funções no acompanhamento e controle social da aplicação dos recursos do Fundo, exercendo, assim, a sua cidadania com mais conscientização, concorrendo, dessa forma, para a busca do efetivo controle social e da democracia plena, fatores essenciais para a co-gestão da coisa pública. 


\section{CONSIDERAÇÕES FINAIS}

Conforme já mencionado neste trabalho, Bobbio (1992, p. 29) enfatiza que “a liberdade e a igualdade dos homens não são um dado de fato, mas um ideal a perseguir; não são uma existência, mas um valor; não são um ser, mas um dever ser”. Ao longo deste trabalho foi demonstrado como a participação cidadã muito pode contribuir para repercussões importantes na gestão da coisa pública, produzindo novos padrões de interações entre o Estado e a sociedade civil organizada, gerando, dessa forma, um exercício de cidadania em busca da governança democrática das cidades, cuja plenitude pretende-se alcançar nos contemporâneos Estados de direitos democráticos. Com esse foco, o papel a ser desempenhado pela representação política da sociedade civil nos conselhos do Fundeb é compatível com a participação significativa dessa sociedade, visto que a posição dominante da literatura estudada é a de que a participação da sociedade civil na gestão da coisa pública pode ser capaz de contribuir para que as administrações adotem políticas orientadas para o real atendimento às necessidades sociais.

A despeito da existência de instituições políticas democráticas no Brasil, os dados de diversas pesquisas apontam para uma precariedade da cidadania no país e sugerem a ausência de uma real cultura política participativa, condição para a consolidação de práticas democráticas. Essa realidade foi reafirmada nesta pesquisa, posto que foram identificados muitos pontos falhos para a prática da cidadania e gestão participativa nos municípios pesquisados nos estados do Maranhão e Piauí.

Verifica-se que o alcance da cidadania depende da transformação das relações de poder, que tem produzido concentração de informação e de saber à custa da ignorância e da exclusão social de muitos cidadãos. Essa transformação deve acontecer nas relações sociais, com o surgimento de novos estilos de gestão pública e de ação coletiva, possibilitando a inclusão da população nos processos políticos decisórios.

Este estudo buscou apresentar aspectos de democracia, cidadania política e da participação cidadã no Brasil, que se configuram na participação dos cidadãos no exercício do poder político e na criação de uma nova prática política que contemple os interesses sociais diversos. No entanto, se por um lado a pesquisa demonstra que existe um número considerável de cidadãos desinteressados pela coisa pública, por outro lado, há uma parcela, mesmo pequena, comprometida com o exercício de sua cidadania, que acredita que sua participação pode alterar os resultados e as decisões políticas de interesse da comunidade. Todavia, a melhor forma de fortalecer esse instrumento participativo é compreender a sua natureza 
jurídica e política, o seu alcance e os seus limites. O não entendimento desses fatores por parte dos integrantes dos conselhos do Fundeb canaliza as energias dos representantes mais politizados da sociedade para confrontos desnecessários ou, de outros, para o abandono de seus ideais de mudanças. Por outro lado, a representatividade inadequada da sociedade civil nos conselhos provoca posturas oportunistas de alguns conselheiros, que visam apenas obter vantagens para si ou para sua categoria, aceitando conchavos com o Poder Executivo local.

Dessa visão depreende-se que o controle público como forma de administrar e de conduzir o bem público, não depende apenas de sua implementação em lei. Ele decorre de ações dotadas de maior abrangência, por implicar em processos culturais e políticos de transformação da organização social. No caso do Fundeb, faz-se necessária a implementação de processos de mudanças das relações de poder dos entes federados com os usuários de seus recursos, além, obviamente, de exigir mudanças de postura dos cidadãos que se dispõem a representar a sociedade civil na gestão da res publica.

E para um bom desempenho da gestão da coisa pública é necessário que haja uma combinação entre o interesse do cidadão em acompanhar e exigir uma boa qualidade dos serviços com o interesse do gestor em informar e ser informado sobre suas falhas, com o objetivo comum, tanto do cidadão quanto do gestor, de aprimorar cada vez mais suas ações e possibilitar visibilidade e transparência no exercício da gestão participativa.

Nesse sentido, a avaliação da operacionalização dos conselhos do Fundeb no Maranhão e Piauí, objeto deste estudo, como estratégia de participação democrática, cidadã e participativa da sociedade, sinaliza que uma grande parte desses colegiados ainda se encontra distante de se constituírem em órgãos que interfiram de forma legítima e contundente na condução das políticas públicas educacionais, caracterizando-se mais como legitimadores de um discurso de participação e cidadania que não guardam muita coerência com a prática rotineira desses colegiados.

Por fim, considerando a importância do tema e os dados apresentados, sugere-se a realização de estudos mais aprofundados em outros estados da Federação, que produzam mais dados empíricos primários que possam se referenciar em conceitos que se compatibilizem com o funcionamento e desempenho dos Conselhos de Acompanhamento e Controle Social do Fundeb, especialmente no que concerne ao cumprimento da legislação que o regulamenta e à capacitação dos conselheiros voltada para conscientização de seus direitos e potencialidades para a co-gestão da administração pública e dos processos decisórios, fazendo com que, dessa forma, esses representantes da sociedade executem suas funções eficientemente, diante dos desafios apresentados às redes públicas de ensino pelo emprego de processos de gestão 
descentralizados e democráticos, que, se não forem bem conduzidos e operacionalizados em parceria com todos os envolvidos no processo, podem comprometer a mobilização social e o próprio exercício da cidadania. 


\section{REFERÊNCIAS}

AGUILLAR, Fernando Herren. Controle social e controle estatal de serviços públicos. In: Controle social de serviços públicos no Brasil. São Paulo: Max Limonad, 1999.

ALLEBRANDT, Sérgio Luis. A participação da sociedade na gestão pública. Ijuí: Unijuí, 2002.

ARENDT, Hannah. As esferas pública e privada. In: A Condição Humana. Rio de Janeiro: Forense Universitária, 2007.

O que é política? 6a edição. Rio de Janeiro: Bertrand Brasil, 2006.

AVRITZER. Leonardo. Teoria Democrática, Esfera pública e participação local. In: Revista Sociologias, Porto Alegre, v. 1, n. 2, p. 18-43, 2000.

BOBBIO, Norberto. A era dos direitos. 18 ${ }^{\mathrm{a}}$ tiragem. Rio de Janeiro: Campus, 1992.

O futuro da democracia. $10^{a}$ edição. São Paulo: Paz e Terra, 2006.

BOVERO, Michelangelo. Contra o governo dos piores: uma gramática da democracia. Rio de Janeiro: Campus, 2002.

BRASIL. Constituição da República Federativa do Brasil. 27a edição. Brasília, Câmara dos Deputados, Centro de Documentação e Informação, 2007.

Decreto $\mathrm{n}^{0}$ 6.253, de 13 de novembro de 2007. Dispõe sobre o Fundo de Manutenção e Desenvolvimento da Educação Básica e de Valorização dos Profissionais da Educação (Fundeb), regulamenta a Lei no 11.494, de 20 de junho de 2007, e dá outras providências.

Emenda Constitucional $\mathbf{n}^{\circ}$ 53, de 19 de dezembro de 2007. Dá nova redação aos arts. $7^{\circ}, 23,30,206,208,211$ e 212 da Constituição Federal e ao art. 60 do Ato das Disposições Constitucionais Transitórias.

Lei $\mathbf{n}^{\mathbf{0}}$ 11.494, de 20 de junho de 2007. Regulamenta o Fundeb, de que trata o art. 60 do Ato das Disposições Constitucionais Transitórias; altera a Lei $\mathrm{n}^{0} 10.195$, de 14 de fevereiro de 2001; revoga dispositivos das Leis $n^{0}$ 9.424, de 24 de dezembro de 1996, 10.880, de 9 de junho de 2004, e 10.845, de 5 de março de 2004; e dá outras providências.

Lei $\mathbf{n}^{0} \mathbf{8 . 0 7 8}$, de 11 de setembro de 1990 . Dispõe sobre a proteção do consumidor e dá outras providências.

Lei $\mathbf{n}^{0}$ 8.987, de 13 de fevereiro de 1995. Dispõe sobre o regime de concessão e permissão da prestação de serviços públicos, previsto no art. 175 da Constituição Federal e dá outras providências.

Lei $\mathrm{n}^{\circ}$ 9.394, de 20 de dezembro de 1996. Estabelece as diretrizes e bases da educação básica.

Ministério da Educação (MEC) - Fundo Nacional de Desenvolvimento da Educação 
(FNDE). Manual de Orientação do Fundeb - 2008. Brasília. 2008.

Ministério da Fazenda. Portaria no 317, de 16/06/2008.

Ministério da Saúde. O SUS e o controle social: Guia para Conselheiros Municipais. Brasília. 1998.

CARVALHO, José Murilo. Cidadania no Brasil: o longo caminho. Rio de Janeiro: Civilização Brasileira, 2004.

COELHO, Maria Francisca. A ambigüidade da democracia no Brasil. XIII Congresso Brasileiro de Sociologia, Recife, PE, junho, 2007.

DAGNINO, Evelina. Sociedade Civil, espaços públicos e a construção democrática no Brasil: limites e possibilidades. In:

Brasil. São Paulo: Paz e Terra, 2002. (org). Sociedade Civil e espaços públicos no

DALLARI, Dalmo de Abreu. O que é participação política. São Paulo: Brasiliense, 2004.

DROPA, Romualdo Flávio. Controle social. Net, Brasília, out. 2008. Artigos jurídicos. Disponível em http://www.advogado.adv.br/artigos/2003. Acesso em: 11 jul. 2008.

GIDDENS, Anthony. A terceira via e seus críticos. Rio de Janeiro - São Paulo: Record, 2001.

GOHN, Maria da Glória. O Papel dos Conselhos Gestores na Gestão Urbana. In: TORRES, Ana Clara; RIBEIRO, Emílio Tadei. (Org.). Repensando a Experiência Urbana na América Latina: questões, conceitos e valores. Buenos Aires: CLACSO, 2000.

GRAU, Nuria. Responsabilização pelo controle social. In: PEREIRA, Luiz Carlos Bresser; GRAU Nuria (coords). Responsabilização na administração pública. São Paulo: CLAD/Fundap, 2006.

HABERMAS, Jürgen. Mudança estrutural da esfera pública: investigações quanto a uma categoria da sociedade burguesa. $2^{\mathrm{a}}$ edição. Rio de Janeiro: Tempo Brasileiro, 2003.

LAVALLE, Adrian Gurza; HOUTZAGER, Peter P. e CASTELLO, Graziela. Representação política e organizações civis: novas instâncias de mediação e os desafios da legitimidade. Revista Brasileira de Ciências Sociais, v.21, n 60, fev. 2006.

LEAL, Sayonara de Amorim Gonçalves. Os mecanismos de controle-público/social presentes no regulamento do setor de telecomunicações no Brasil: a lei geral de telecomunicações e o regimento interno da agência nacional de telecomunicações, 2001. 294f, Dissertação (Mestrado em Comunicação) - Faculdade de Comunicação, Universidade de Brasília, Brasília.

LEAL, Sayonara de Amorim Gonçalves; RIBEIRO, Lavina Madeira. A imaginação de um controle público a partir do regulamento do Setor de Telecomunicações no Brasil: a utilização dos aparatos regulatórios da Agência Nacional de Telecomunicações pelo usuáriocidadão. Revista de Economía Política de las Tecnologías de la Información y Comunicación, v. IV, 2002. 
LUCA, Tânia Regina de. Direitos Sociais no Brasil. In: PINSKI, Jaime; PINSKI, Carla Bassanezi. História da Cidadania. São Paulo: Contexto, 2003.

MARSHALL, Thomas Humprey. Cidadania, classe social e status. Tradução de Meton Porto Gadelha. Rio de Janeiro: Zahar, 1967.

OLIVEIRA, Francisco Mesquita de. Cidadania e cultura política no poder local. Fortaleza: Fundação Konrad Adenauer, 2003.

PATEMAN, Carole. Participação e Teoria Democrática. Rio de Janeiro: Paz e Terra, 1992.

PEREIRA, Luiz Carlos Bresser. A reforma do Estado dos anos 90: lógica e mecanismos de controle. Brasília: MARE, 1997.

. Sociedade Civil: sua democratização para reforma do Estado. In PEREIRA, Luiz

Carlos Bresser; WILHEIN, Jorge; SOLA, Lourdes. Sociedade e Estado em Transformação. São Paulo: Editora UNESP; Brasília: Editora ENAP, 1999.

PEREZ, Marcos Augusto. A Administração Pública Democrática: Institutos de Participação Popular na Administração Pública. Belo Horizonte: Fórum, 2004.

SANTOS, Boaventura de Sousa (org.). Democratizar a democracia: os caminhos da democracia participativa. Rio de Janeiro: Civilização Brasileira, 2002.

SILVA, Francisco Carlos da Cruz. Controle social: reformando a administração para a sociedade. 2001. 72 f. Monografia. In: Prêmio Serzedello Correa: Perspectivas para o Controle Social e a Transparência da Administração Pública. Brasil, Tribunal de Contas da União, Brasília, 2001.

TATAGIBA, Luciana. Os conselhos gestores e a democratização das políticas públicas no Brasil. In: Dagnino, Evelina (org.) Sociedade civil e espaços públicos no Brasil. São Paulo: Paz e Terra, 2002.

TEDESCO, Juan Carlos. Tendências atuais das reformas educacionais. In: DELORS, Jacques (org). A educação para o século XXI - questões e perspectivas. Tradução: Fátima Murad. Porto Alegre: Artmed, 2005.

TEIXEIRA, Ana Cláudia Chaves. A atuação das organizações não governamentais: entre o Estado e o conjunto da sociedade. In: DAGNINO, Evelina (org). Sociedade Civil e espaços públicos no Brasil. São Paulo: Paz e Terra, 2002.

VERGARA, Sylvia Constant. Projetos e Relatórios de Pesquisa em Administração. São Paulo: Atlas, 2004.

VIEIRA, Liszt. Os argonautas da cidadania: a sociedade civil na globalização. Rio de Janeiro/São Paulo: Record, 2001.

YIN, Robert K. Estudo de Caso: Planejamento e Métodos. Porto Alegre: Bookman, 2003. 